\title{
RESÍDUOS DE DELTAMETRINA EM GRÃOS DE TRIGO, MILHO E MILHO PIPOCA E EM SEUS PRODUTOS PROCESSADOS DETERMINADOS POR CROMATOGRAFIA EM FASE GASOSA.
}

\author{
LUIZ ROBERTO PIMENTEL TREVIZAN \\ (Engenheiro Agrônomo)
}

Orientador: Prof. Dr. GILBERTO CASADEI DE BAPTISTA

Dissertação apresentada à Escola Superior de Agricultura "Luiz de Queiroz", Universidade de São Paulo, para obtenção do título de Mestre em Ciências, Área de Concentração: Entomologia.

PIRACICABA

Estado de São Paulo - Brasil

Novembro - 1998 
Dados Internacionais de Catalogacão na Publicacão (CIP) DIVISÃO DE BIBLIOTECA E DOCUMENTAÇÃO - Campus "Luiz de Queiroz"/USP

Trevizan, Luiz Roberto Pimentel

Residuos de deltametrina em grāos de trigo, milho e milho pipoca e em seus produtos processados determinados por cromatografia em fase gasosa / Luiz Roberto Pimentel Trevizan. - - Piracicaba, 1998.

$74 \mathrm{p}$.

Dissertaçāo (mestrado) - Escola Superior de Agricultura Luiz de Queiroz, 1998. Bibliografia.

1. Alimento processado 2. Cromatografia gasosa 3. Grāo armazenado 4. Inseticida piretróide 5. Residuo de inseticida 1. Titulo 
Aos meus queridos avós Silvino e Elvira que sempre fizeram o melhor possível pelo seu neto.

Dedico e Ofereço 


\section{AGRADECIMENTOS}

Ao Prof. Dr. Gilberto Casadei de Baptista pelos ensinamentos e orientação na realização deste trabalho.

Ao Conselho Nacional de Desenvolvimento Científico e Tecnológico - CNPq pela concessão da bolsa de estudo.

Ao Prof. Dr. Celso Omoto pela revisão do summary.

A Ricardo e Carlos pela ajuda no laboratório.

À Ana e Regina, do Centro de Processamento de Dados do Departamento de Entomologia, pela ajuda na editoração do trabalho.

À bibliotecária Eliana pela correção das Referências Bibliográficas e demais funcionários da Biblioteca Central pela colaboração.

À Cargill Agrícola S.A., Fecularia Santa Teresinha, Departamento de Agricultura e a minha tia Leanine pelo processamento dos diversos substratos utilizados no experimento.

À Fundação de Amparo à pesquisa do Estado de São Paulo - FAPESP pela ajuda financeira para o desenvolvimento dessa pesquisa. 


\section{SUMÁRIO}

Página

LISTA DE FIGURAS............................................................................... vi

LISTA DE QUADROS.............................................................................. viii

LISTA DE TABELAS................................................................................. ix

RESUMO............................................................................................. xii

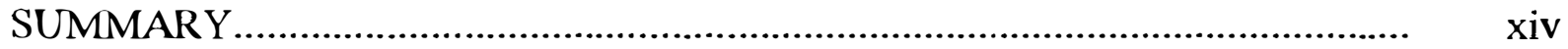

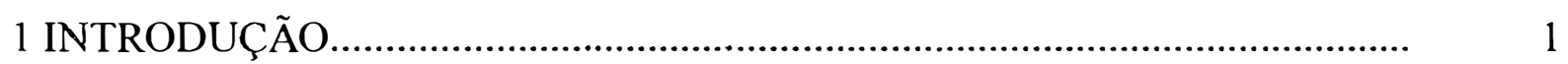

2 REVISÃO DE LITERATURA...................................................................... 3

2.1 Características da deltametrina..................................................................... 3

2.2 Comportamento dos inseticidas em grãos armazenados e seus produtos annazenados.............................................................................................. 5

3 MATERIAL E MÉTODOS....................................................................... 15

3.1 Experimentos de degradação e persistência dos resíduos de deltametrina....... $\quad 15$

3.2 Processamento dos grãos............................................................................. 16

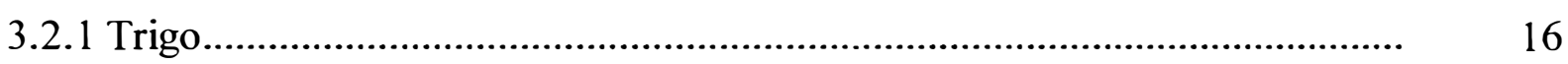

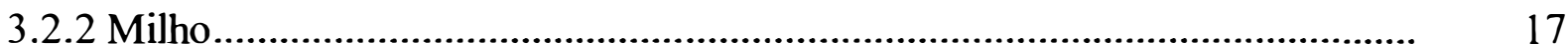

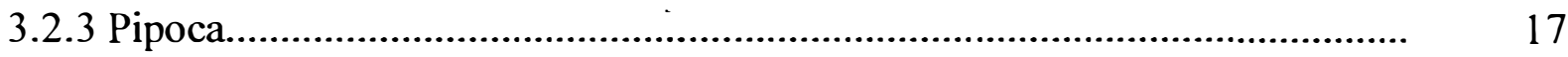

3.3 Limites de quantificação, porcentagens de recuperação e métodos de análise

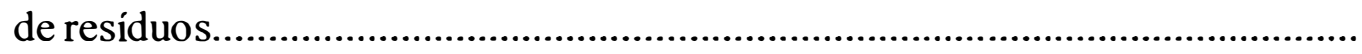

3.3.1 Método de análises de resíduos de deltametrina em grãos cereais e seus produtos processados.......................................................................................... 18

3.3.1.1 Reagentes..................................................................................... 18

3.3.1.2 Aparelhos, vidrarias e outros materiais................................................ 19

3.31.3 Marcha analítica................................................................................. 20 
v

Página

4 RESULTADOS E DISCUSSÃO

23

4.1 Resíduos de deltametrina em grãos de trigo e em seus produtos processados.

23

4.2 Resíduos de deltametrina em grãos de milho e em seus produtos processados.

4.3 Resíduos de deltametrina em grãos de pipoca e em pipoca.

32

4.4 Análise de umidade de grãos e seus produtos processados

39

4.5 Limite de quantificação e porcentagem de recuperação dos métodos.

45

5 CONCLUSÕES

49

REFERÊNCIAS BIBLIOGRÁFICAS.

65

APÊNDICES

66

72 


\section{LISTA DE FIGURAS}

Página

1 Fórmula estrutural plana de deltametrina....................................................... 4

2 Cromatogramas de extratos de grão de trigo..................................................... 53

3 Cromatogramas de extratos de farelo de trigo. .......................................... 54

4 Cromatogramas de extratos de farinha branca............................................... 55

5 Cromatogramas de extratos de farinha integral......................................... 56

6 Cromatogramas de extratos de pão integral................................................ 57

7 Cromatogramas de extratos de grão de milho............................................. 58

8 Cromatogramas de extratos de canjica........................................................ 59

9 Cromatogramas de extratos de farelo de milho............................................ 60

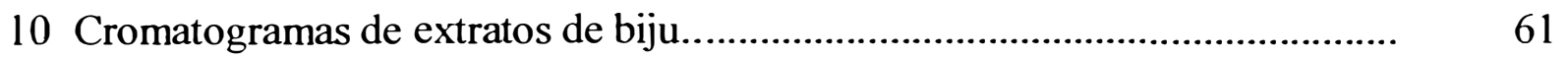

11 Cromatogramas de extratos de farelinho...................................................... 62

12 Cromatogramas de extratos de grão de milho pipoca........................................... 63 
Página

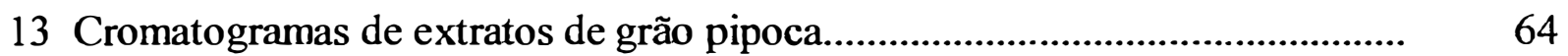




\section{LISTA DE QUADROS}

Página

1 Limites máximos de resíduos de defensivos agrícolas em produtos processados de grãos armazenados.. 


\section{LISTA DE TABELAS}

Página

1 Resíduos de deltametrina em grãos de trigo, tratados com $0,35 \mathrm{mg} \cdot \mathrm{kg}^{-1}$ do inseticida, e em seus produtos processados e concentração dos resíduos após cada etapa de beneficiamento, zero dia após a aplicação

2 Resíduos de deltametrina em grãos de trigo, tratados com $0,35 \mathrm{mg} \cdot \mathrm{kg}^{-1}$ do inseticida, e em seus produtos processados e concentração dos resíduos após cada etapa de beneficiamento, 15 dias após a aplicação

3 Resíduos de deltametrina em grãos de trigo, tratados com $0,35 \mathrm{mg} \cdot \mathrm{kg}^{-1}$ do inseticida, e em seus produtos processados e concentração dos resíduos após cada etapa de beneficiamento, 30 dias após a aplicação

4 Resíduos de deltametrina em grãos de trigo, tratados com $0,35 \mathrm{mg} \cdot \mathrm{kg}^{-1}$ do inseticida, e em seus produtos processados e concentração dos resíduos após cada etapa de beneficiamento, 60 dias após a aplicação

5 Resíduos de deltametrina em grãos de trigo, tratados com $0,35 \mathrm{mg} \cdot \mathrm{kg}^{-1}$ do inseticida, e em seus produtos processados e concentração dos resíduos após cada etapa de beneficiamento, 90 dias após a aplicação

6 Resíduos de deltametrina em grãos de milho, tratados com $0,35 \mathrm{mg} \cdot \mathrm{kg}^{-1}$ do inseticida, e em seus produtos processados e concentração dos resíduos após cada etapa de beneficiamento, 0 dia após a aplicação 
7 Resíduos de deltametrina em grãos de milho, tratados com $0,35 \mathrm{mg} \cdot \mathrm{kg}^{-1}$ do inseticida, e em seus produtos processados e concentração dos resíduos após cada etapa de beneficiamento, 15 dias após a aplicação.

8 Resíduos de deltametrina em grãos de milho, tratados com $0,35 \mathrm{mg} \cdot \mathrm{kg}^{-1}$ do inseticida, e em seus produtos processados e concentração dos resíduos após cada etapa de beneficiamento, 30 dias após a aplicação.

9 Resíduos de deltametrina em grãos de milho, tratados com $0,35 \mathrm{mg} \cdot \mathrm{kg}^{-1}$ do inseticida, e em seus produtos processados e concentração dos resíduos após cada etapa de beneficiamento, 60 dias após a aplicação.

10 Resíduos de deltametrina em grãos de milho, tratados com 0,35 mg. $\mathrm{kg}^{-1}$ do inseticida, e em seus produtos processados e concentração dos resíduos após cada etapa de beneficiamento, 90 dias após a aplicação

11 Resíduos de deltametrina em grãos de pipoca, tratados com $0,35 \mathrm{mg} \cdot \mathrm{kg}^{-1}$ do inseticida, e em seus produtos processados e concentração dos resíduos após cada etapa de beneficiamento, zero dia após a aplicação.

12 Resíduos de deltametrina em grãos de pipoca, tratados com $0,35 \mathrm{mg} \cdot \mathrm{kg}^{-1}$ do inseticida, e em seus produtos processados e concentração dos resíduos após cada etapa de beneficiamento, 15 dias após a aplicação

13 Resíduos de deltametrina em grãos de pipoca, tratados com 0,35 mg. $\mathrm{kg}^{-1}$ do inseticida, e em seus produtos processados e concentração dos resíduos após cada etapa de beneficiamento, 30 dias após a aplicação

14 Resíduos de deltametrina em grãos de pipoca, tratados com $0,35 \mathrm{mg} \cdot \mathrm{kg}^{-1}$ do inseticida, e em seus produtos processados e concentração dos resíduos após cada etapa de beneficiamento, 60 dias após a aplicação. 
Página

15 Resíduos de deltametrina em grãos de pipoca, tratados com $0,35 \mathrm{mg} \cdot \mathrm{kg}^{-1}$ do inseticida, e em seus produtos processados e concentração dos resíduos após cada etapa de beneficiamento, 90 dias após a aplicação

16 Resultados de análise de umidade em trigo

17 Resultados de análise de umidade em milho

18 Resultados de análise de umidade em milho pipoca.

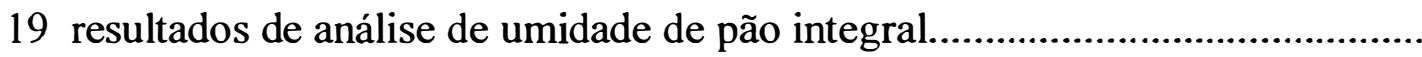

20 Resultados de análise de umidade de pipoca.

21 Dados de temperatura média (TM) e de umidade relativa média (URM) do local de armazenamento durante o período do experimento.

22 Porcentagem (\%) de recuperação de deltametrina, pelo método de análise de resíduos em amostras de grãos de trigo e seus produtos processados.

23 Porcentagem (\%) de recuperação de deltametrina, pelo método de análise de resíduos em amostras de grãos de milho e seus produtos processados...........

24 Porcentagem (\%) de recuperação de deltametrina, pelo método de análise de resíduos em amostras de grãos de milho pipoca e seus produtos processados. 


\title{
RESÍDUOS DE DELTAMETRINA EM GRÃOS DE TRIGO, MILHO E MILHO PIPOCA E EM SEUS PRODUTOS PROCESSADOS DETERMINADOS POR CROMATOGRAFIA EM FASE GASOSA.
}

\author{
Autor: LUIZ ROBERTO PIMENTEL TREVIZAN \\ Orientador: Prof. Dr. GILBERTO CASADEI DE BAPTISTA
}

\section{RESUMO}

O objetivo do presente estudo foi avaliar a degradação/persistência do inseticida piretróide deltametrina em grãos cereais e em seus produtos processados, a saber: trigo: grão, farelo, farinha branca, farinha integral e pão; milho: grão, farelo, canjica, farelinho e biju; milho pipoca: grão e pipoca.

Os grãos foram tratados de modo a se obter a concentração teórica de 0,35 mg.kg ${ }^{-1}$ de deltametrina, aplicando-se 5 litros de calda preparada por tonelada de grãos. O delineamento experimental foi inteiramente ao acaso, com 3 repetições. As amostras foram tomadas a zero, 15, 30, 60 e 90 dias após a aplicação para quantificações dos resíduos e mensalmente para análise de umidade dos grãos.

O método analítico constou de extração com uma mistura de hexano + éter etílico $(1 / 1 \mathrm{v} / \mathrm{v})$, limpeza com partição em acetonitrilo/hexano e coluna cromatográfica de sílica eluída com mistura de hexano + éter etílico $(9 / 1 \mathrm{v} / \mathrm{v})$ e 
O método analítico constou de extração com uma mistura de hexano + éter etílico $(1 / 1 \mathrm{v} / \mathrm{v})$, limpeza com partição em acetonitrilo/hexano e coluna cromatográfica de sílica eluída com mistura de hexano + éter etílico $(9 / 1 \mathrm{v} / \mathrm{v})$ e concentração dos extratos. A determinação quantitativa foi realizada em cromatógrafo a gás, equipado com detector de captura de elétrons $\left(\mu-\mathrm{ECD}, \mathrm{NI}^{63}\right)$. Foram analisadas 240 amostras no total, sendo 60 de grãos cereais e 180 de seus produtos processados.

Os limites de quantificação dos resíduos pelo método de análise, para os diferentes substratos, foram de 0,01 a $0,05 \mathrm{mg} \cdot \mathrm{kg}^{-1}$. Os resíduos de deltametrina mostraram ser persistentes e estáveis durante o armazenamento dos grãos (90 dias). Houve tendência de concentração do piretróide no farelo de trigo e um menor acúmulo nas farinhas, sendo que após o processo de cozimento do pão observou-se perda do inseticida. A quase totalidade da deltametrina aplicada em grãos de milho permaneceu no farelo e muito pouco penetrou para o endosperma, do qual se obteve a canjica, farelinho e biju, sendo que para a pipoca, feita em forno microondas, obtida a partir de grãos de milho pipoca com o tratamento inseticida, observou-se concentração dos resíduos de deltametrina. 


\title{
DELTAMETHRIN RESIDUES IN WHEAT, CORN AND POPCORN GRAINS AND IN THEIR PROCESSED PRODUCTS DETERMINED BY GAS CHROMATOGRAPHY
}

\author{
Author: LUIZ ROBERTO PIMENTEL TREVIZAN \\ Adviser: Prof. Dr. GILBERTO CASA DEI DE BAPTISTA
}

\section{SUMMARY}

The objective of this research was evaluate the degradation/persistence of the pyrethroid insecticide deltamethrin in cereal grains and their processed products, such as: bran, white flour, whole meal flour and bread; for wheat, bran, "canjica", "farelinho", "biju" (corn flour); for corn and popcorn.

The grains were treated with $0.35 \mathrm{~g} \mathrm{A.I.} \mathrm{of} \mathrm{deltamethrin/ton.} \mathrm{An} \mathrm{amount} \mathrm{of} 5$ liters of solution was applied per ton of grain. The experimental design was completely randomized with three replicates. Samples were taken at zero, 15, 30, 60 and 90 days after the application to analyze the insecticide residues and monthly to determine the moisture content in the grains.

The residue analysis consisted of extraction with a mixture of hexane + ethyl ether, clean-up by partition with acetonitrile/hexane and silica column chromatography eluted with a mixture of hexane + ethyl ether, and concentration of the extracts. The quantitative measurement of the residue was determined by gas chromatography, equipped with electron capture detector $\left(\mu-\mathrm{ECD}, \mathrm{Ni}^{63}\right)$. A total of 
240 samples, were analyzed (60 samples of cereal grains and 180 of their processed products).

The detection limits for the different substrates, were 0.01 at $0.05 \mathrm{mg} \cdot \mathrm{kg}^{-1}$. The residues of deltamethrin demonstrated to be persistent and stable during the period of 90 days of storage. It was observed a higher pyrethroid concentration in wheat bran and lower accumulation in flour of this cereal, and insecticide loss was detected after baking the bread. Most of deltamethrin applied on corn grains was found on the corn bran, and a small amount penetread into endosperm, from with, "canjica", "farelinho" and "biju", were obtained. High deltamethrin residues were detected in the popcorn preapered in a microwave oven. 


\section{INTRODUÇĀO}

Estima-se que $20 \%$ da produção nacional de grãos é perdida anualmente nos processos de colheita, de transporte e de armazenamento. Grande parte destas perdas deve-se a problemas fitossanitários, sendo somente as pragas de armazéns responsáveis por cerca de $10 \%$ delas ou aproximadamente 7 milhões de toneladas de grãos.

Este problema assume maior significado considerando-se a grande importância dos grãos cereais na alimentação humana, o expressivo contingente de brasileiros vivendo em estado de desnutrição e, ainda, o fato de que certa parte dos investimentos públicos e privados, aplicados na produção de grãos, perde-se depois da colheita por efeito daqueles eventos.

Em razão dos problemas causados pelos insetos nos armazéns, tem-se usado principalmente substancias químicas para controlar estas pragas e para preservação das colheitas; por outro lado, pode ocorrer a persistência destes inseticidas na forma de resíduos tóxicos nos grãos tratados, cujo consumo por parte do homem e dos animais, mesmo em quantidade sub-letais, representa risco potencial à saúde dos consumidores.

O controle de pragas de grãos armazenados assume maior importância nos países de clima tropical ou semitropical do que nos países de clima temperado, onde as baixas temperaturas durante o inverno reduzem a atividades dos insetos. Durante o armazenamento de cereais os insetos podem causar aquecimento e migração de umidade na massa de grãos, os quais podem levar ao um aumento na produção de micotoxinas, 
um perigo talvez maior do que a presença de níveis tolerados de resíduos de inseticidas neles (Webley,1994).

O controle oficial de resíduos de pesticidas em alimentos é geralmente baseado nas tolerâncias (limites máximos de resíduos) e períodos de carência (intervalos de segurança), estabelecidos caso a caso. Alguns estudos sobre a ocorrência de resíduos em grãos já são conhecidos entre nós. Entretanto, quase nada se sabe a respeito da ocorrência deles nos produtos processados e, em conseqüência, os riscos à saúde; de estudos estrangeiros, sabe-se que o processamento, em geral, reduz os resíduos nos produtos industrializados, mas em outros casos aumenta.

Há uma grande quantidade de dados sobre resíduos em produtos oriundos de grãos armazenados; entretanto, muitos desses não são publicados na literatura mas incluídos em subcomissões para o Codex Alimentarius (Desmarchelier, 1994).

Estudos sobre efeitos de armazenamento e algumas técnicas de processamento comerciais, em relação aos resíduos nos alimentos fazem parte da exigência para registro de pesticidas em muitos países. O JMPR, Comitê da FAO/OMS, considera efeitos de processamento como parte de suas revisões de dados de resíduos de pesticidas (Holland et al., 1994).

Para o registro de algum produto a ser usado em grãos armazenados, o governo da Austrália exige dados de resíduos sobre dois produtos processados obtidos a partir desses grãos tratados, sendo as análises feitas por um laboratório certificado (Desmarchelier, 1994).

Justifica-se o presente trabalho, pela necessidade inadiável de se obter dados, nas condições brasileiras, sobre influência do processamento nos níveis de resíduos de pesticidas em produtos agrícolas usados na alimentação humana e animal, dados esses raros na literatura nacional.

Assim, foi conduzido o presente trabalho, cujo o principal objetivo foi estudar o comportamento do inseticida piretróide deltametrina em grãos de trigo, milho e milho pipoca e em seus produtos processados. 


\section{REVISÃO DE LITERATURA}

\subsection{Características da deltametrina}

A deltametrina é um composto químico piretróide sintético resultante do isolamento de apenas um isômero, o mais ativo, (D-cis). Devido à dose extremamente baixa recomendada por área, ele se apresenta altamente seguro, com resíduos desprezíveis sobre as culturas, eliminado o risco para o consumidor. É altamente tóxico para peixes, devendo-se portanto tomar cuidado com aplicações próximas ao habitat desses animais, sendo a intoxicação de abelhas evitada devido ao efeito de repelência do inseticida sobre esses insetos (Gallo et al., 1988).

Segundo Tessier (1983), a deltametrina é um produto pouco polar, o que lhe confere baixa solubilidade em água e em outros solventes hidrófilos. Sendo solúvel em acetona, acetato de etila, benzeno e tolueno. Possui grande estabilidade térmica, sendo que, colocada a $100^{\circ} \mathrm{C}$ durante $24 \mathrm{~h}$ não apresenta qualquer degradação; a $150^{\circ} \mathrm{C}$ durante o mesmo período ocorre uma pequena degradação e somente a $190^{\circ} \mathrm{C}$ observam-se perdas importantes desse inseticida. 
Este piretróide tem o nome químico (S)- $\alpha$-ciano-3-fenoxibenzil(1R,3R)-3(2,2dibromovinil)-2,2-dimetil ciclopropano carboxilate, fórmula molecular, $\mathrm{C}_{22} \mathrm{H}_{19} \mathrm{Br}_{2} \mathrm{NO}_{3}$ e fórmula estrutural plana (Figura 1)(Tomlin, 1995). Seu peso molecular é de 505.2, ponto de fusão, 100 a $102^{\circ} \mathrm{C}$ e pressão de vapor $<1.33 \times 10^{-5} \mathrm{~Pa}\left(25^{\circ} \mathrm{C}\right)$. $\mathrm{A}$ dose letal $50\left(\mathrm{DL}_{50}\right)$ aguda oral para ratos varia de $135 \mathrm{a}>5000 \mathrm{mg} \cdot \mathrm{kg}^{-1}$, dependendo da formulação usada e das condições do teste, sendo sua ingestão diária aceitável (IDA) de 0,01 mg. $\mathrm{kg}^{-1}$ de peso vivo.

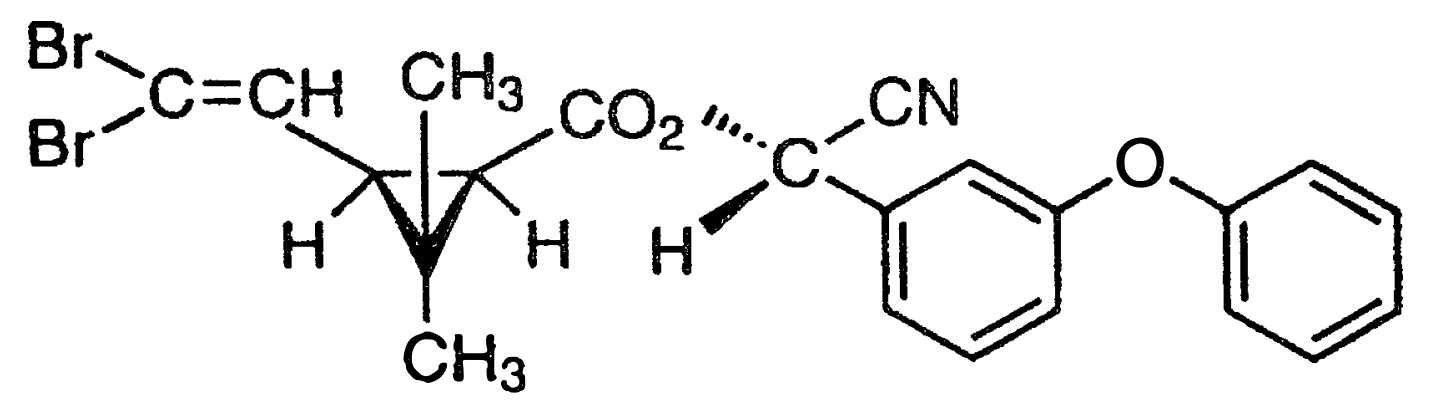

Figura 1. Fórmula estrutural plana de deltametrina

De acordo com ILSI Brasil (1995), a deltametrina é registrada para aplicação em partes aéreas das culturas de algodão, alho, amendoim, ameixa, arroz, batata, beringela, brócolis, café, cebola, citrus, couve, couve-flor, figo, feijão, maçã, melancia, melão, milho, pêssego, pepino, pimentão, repolho, soja, sorgo, trigo, tomate e vagem, em grãos armazenados de feijão, milho e trigo; e em produtos ensacados e armazenados de arroz, café, feijão e milho. 
Para o uso no controle de pragas de grãos armazenados é comercializada com o nome de K-Obiol 25 CE e K-Obiol 2 P, sendo no primeiro apresentada na forma de concentrado emulsionável e sinergizada com butóxido de piperonila e no segundo é vendida na forma de pó seco (Andrei, 1996). Em grãos de trigo e milho a tolerância é de 1,0 mg. $\mathrm{kg}^{-1}$ (ppm) e o intervalo de segurança de 30 dias (ILSI Brasil, 1995).

\subsection{Comportamento dos inseticidas em grãos armazenados e seus produtos} processados.

$\mathrm{Na}$ utilização de produtos químicos em mistura com os grãos, visando sua proteção contra o ataque de pragas, deve-se considerar as normas relacionadas com os resíduos, que definem as tolerâncias (limites máximos de resíduos) e os intervalos de segurança (períodos de carência) variáveis para consumo, de acordo com o inseticida empregado e o tipo de grão ou produto em questão.

Experimentos com produtos obtidos a partir da moagem de trigo, foram feitos por Schesser et al. (1958) para determinar os resíduos de metoxicloro, malation e lindane na farinha de trigo. A maior parte dos resíduos ficou concentrada no farelo e muito pouco dos inseticidas foi levado para a farinha, sendo os resíduos encontrados neste ultimo produto de 0 a $0,3 \mathrm{mg} \cdot \mathrm{kg}^{-1}$ para malation aplicado nas concentrações de 2,5 e 7,5 mg.kg-1 $; 0,3$ a 1,8 mg.kg ${ }^{-1}$ para metoxicloro nas concentrações de 5 e 50 mg.kg ${ }^{-1}$ e de 1,3 a 2,6 mg. $\mathrm{kg}^{-1}$ para lindane aplicado a 2,5 e $7,5 \mathrm{mg} \cdot \mathrm{kg}^{-1}$. 
McGaughey (1971), utilizando três variedades de arroz, cada uma tratada com 14, 21 e $28 \mathrm{mg} \cdot \mathrm{kg}^{-1}$ de malation, observou que o inseticida localizava-se, preferencialmente na casca e no farelo, sendo muito pouco dele encontrado no arroz polido. A concentração desse organofosforado na casca e no grão mostrou queda rápida nos primeiros três meses após o tratamento, ao contrário do farelo e arroz polido nos quais obtiveram picos máximos de concentração passado o período de dois meses, evidenciando translocação dos resíduos da região periférica para a central. O autor ainda observou que a intensidade desta translocação é afetada pela espessura e área específica da casca de cada variedade.

A viabilidade do uso de fentoato na concentração de $5 \mathrm{mg} \cdot \mathrm{kg}^{-1}$ para tratamento de grãos de trigo, foi estudada por Bazzi et al. (1972). Os autores observaram que o inseticida afetou a qualidade dos produtos obtidos por moagem, além da dos pães derivados desses grãos. A concentração do ingrediente ativo restante na farinha, pão, farelo fino e farelo, cinco meses após o tratamento, foi de 0,$4 ; 0,1 ; 8,3$ e $12,2 \mathrm{mg} \cdot \mathrm{kg}^{-1}$ respectivamente.

Segundo Lockwood (1973), grãos de arroz, trigo e sorgo tratados com malation, Gardona e fenitrotion apresentaram perdas de 30 a $70 \%$ em seus resíduos após o processo de moagem, provavelmente devido a degradação pelo aquecimento do moinho. Preparação de alimentos, a partir das frações moídas desses cereais, envolvendo cozimento, proporcionou degradação completa dos inseticidas.

Em experimentos com grãos de milho e trigo tratados com diclorvós e Gardona, Hall et al. (1973) observaram a concentração destes dois inseticidas nos produtos oriundos das camadas mais externas dos grãos, sendo que a união de farelo e gérmen de 
milho constituía 94 e $100 \%$ dos resíduos de Gardona e diclorvós e o farelo de trigo encerrava 64 e $90 \%$ destes organofosforados, respectivamente.

Durante a análise de produtos obtidos a partir de trigo tratado com $10,4 \mathrm{mg} \cdot \mathrm{kg}^{-1}$ de malation, Kadoum \& La Hue (1977) observaram a tendência de acúmulo do inseticida no farelo e uma diminuição em seus níveis na farinha. Aos 7 dias após a aplicação, os valores do citado organofosforado no grão, farelo e farinha eram de 8,6 ; 16,5 e $2,1 \mathrm{mg} \cdot \mathrm{kg}^{-1}$, sendo esses valores de 1,4;2,2 e 0,2 após 12 meses.

Kadoum et al. (1978) analisaram grãos de trigo contendo 7,3 e $14,6 \mathrm{mg} \cdot \mathrm{kg}^{-1}$ de pirimifos-metil, farelo e farinha, estes dois últimos obtidos através de moagem dos grãos. Após três meses os valores encontrados para grão, farelo e farinha foram de 6,6 ; 20,11 e 1,47 para a menor dosagem e de 12,$98 ; 39,97$ e 3,15 para a maior.

Utilizando grãos de trigo e milho com umidade de 10,12, 14 e 16\%, Kadoum \& LaHue (1979) obtiveram, após três meses, 72, 55, 24 e 23\% dos resíduos iniciais de malation para milho e $68,56,27$ e $23 \%$ para trigo.

Mensah et al. (1979), em estudos conduzidos com malation, bromofós, iodofenfós e pirimifós-metil nas concentrações de 8 e 12 mg.kg ${ }^{-1}$ em grãos de trigo, observaram altas concentrações de resíduos no farelo e baixos níveis na farinha.

O comportamento de phoxim metil foi estudado em grãos de trigo e em seus produtos por Alnaji et al. (1979). Os autores observaram que quantidades muito pequenas do inseticida migraram do pericarpo para o endosperma. $O$ fator de concentração do inseticida no farelo e na farinha, em relação ao grão, foi em média de 3,28 e 0,2 , respectivamente. 
Singh \& Chawla (1980) observaram que em grãos de arroz tratados com pirimifos-metil, 97,2 a 98,3\% do inseticida se encontrava na casca e que a pipoca, obtida de grãos de milho tratados com esse organofosforado, mostrava redução de 81,9 a $77,1 \%$ nos seus níveis de resíduo.

Bengston et al. (1980) compararam os resíduos de diversos produtos em trigo e obtiveram a seguinte ordem decrescente de persistência: pirimifós-metil $>$ fenotrina $>$ carbaril e fenitrotion. Durante o processamento para pão branco, os resíduos foram reduzidos em $98 \%$ para carbaril, $48 \%$ para fenotrina, $98 \%$ para fenitrotion e $85 \%$ para pirimifós-metil. Ainda, Bengston et al. (1983) determinaram que os resíduos de deltametrina, fenvalerato, permetrina e fenotrina são altamente persistentes em trigo armazenado, sendo de 91 semanas a meia vida de deltametrina em grãos com 10 a $11 \%$ de umidade e armazenados à temperatura de $30^{\circ} \mathrm{C}$ e umidade relativa de $50 \%$. Durante a moagem, eles tendem a se acumular no farelo e muito pouco na farinha branca, não se observando redução dos níveis após a operação de cozimento.

A estabilidade de quatro piretróides, aplicados sobre grãos de trigo armazenados em diferentes condições de umidade e temperatura, foi estudada por Noble et al. (1982). Os autores determinaram que a meia vida de deltametrina, em grãos com $12 \%$ de umidade e estocados a 25 e $35^{\circ} \mathrm{C}$ e com $15 \%$ de umidade, nas mesmas temperaturas, foi de $114,90,70$ e 35 semanas, respectivamente.

Visweswaraiah et al. (1983) utilizaram grãos de trigo contendo 32 e 64,8 mg.kg-1 de fenitrotion para moagem e obtenção de farelo, farinha e pão, sendo os resíduos encontrados de 8,4 e $19 ; 0,72$ e 1,6 e 0,1 e $0,18 \mathrm{mg}^{-\mathrm{kg}^{-1}}$, respectivamente para os produtos anteriormente citados. Os autores ainda verificaram que a diminuição dos 
resíduos no pão se deve, provavelmente, à hidrólise de fenitrotion em condição alcalina e metabolismo em outros compostos à alta temperatura.

Após o processo de moagem de grão de trigo, tratados com doses intencionais de 0,5 e 1,0 mg.kg-1 de deltametrina, L'Hotellier (1983) observou perdas médias de $15 \%$ do piretróide. $\mathrm{O}$ autor ainda cita concentrações de 4 a 7 vezes do inseticida no farelo e perdas médias de $84 \%$ na transformação para a farinha, sendo de $27 \%$ para o pão integral obtido a partir do fubá de grãos de trigo.

Joia et al. (1985) observaram perdas de 16 e $21 \%$ no preparo de pão branco e integral preparados com farinhas oriundas de grãos tratados com cipermetrina, sendo que para fenvalerato essas reduções foram de 12 e $13 \%$ respectivamente.

Cogburn et al. (1990) trataram grãos de arroz com malation (14mg.kg-1) e clorpirifós (6 e 12 mg. $\mathrm{kg}^{-1}$ ), os quais foram mantidos em seu estado bruto ou foram parbolizados e a partir desses dois grupos, obtidos casca, arroz beneficiado, farelo, arroz polido e arroz cozido. A parbolização reduziu os resíduos no arroz bruto e na casca, mas mostrou uma tendência de aumentá-los em outras frações. Resíduos de clorpirifós no farelo foram aumentados substancialmente com a parbolização. No geral houve concentração dos inseticidas na casca e farelo e redução nas demais frações.

Sacos de juta contendo milho em espiga e arroz em casca foram tratados com clorpirifós por Tejada et al. (1990), os quais procuraram observar os efeitos da lavagem e processamento sobre os níveis de resíduo do citado inseticida. No caso do milho, após três lavagens houve redução de 78 a $100 \%$ de clorpirifós, sendo essa redução de 57 a 67\% para o arroz. Quando submetido ao cozimento, o inseticida foi totalmente perdido 
durante essa operação no caso do milho e ficou com seus níveis praticamente inalterados no do arroz, devido ao fato do último estar tampado ao contrário do primeiro.

Papadopoulou-Muorkidou et al. (1991) aplicaram permetrina (2 e $\left.8 \mathrm{mg} \cdot \mathrm{kg}^{-1}\right)$ e permetrina + butóxido de piperonila (PBO) $\left(2+2 \mathrm{mg} \cdot \mathrm{kg}^{-1}\right)$ em grãos de trigo e em suas frações moídas. Após 35 dias de armazenamento, 75-80\% dos resíduos foram encontrados no farelo; 427 dias após, eles não foram encontrados na farinha dos grãos tratados com $2 \mathrm{mg} \cdot \mathrm{kg}^{-1}$, sendo encontrados valores de 1,6 e $0,37 \mathrm{mg} \cdot \mathrm{kg}^{-1}$ para a maior dosagem.

A redução dos resíduos de pirimifós-metil, durante o armazenamento de trigo tratado, na dosagem de $4 \mathrm{mg} \cdot \mathrm{kg}^{-1}$ do inseticida, por 1, 3 e 6 meses foi estudada por Brown et al. (1991). As amostras foram submetidas à uma limpeza por atrito para remover parte de suas cascas. Esta operação removeu 17-28\% mais resíduos do inseticida do que a limpeza convencional. Uma grande redução ocorreu quando o pesticida foi aplicado na formulação de pó seco em relação à aplicação na de concentrado emulsionável. Houve maior dificuldade na remoção dos resíduos por este processo, com o aumento do tempo de armazenamento.

Grãos de trigo tratados com pirimifós-metil e suas frações moídas tiveram seus resíduos analisados por Pucceti et al. (1993). Os resultados indicam que o processo de lavagem antes da moagem removeu boa parte dos resíduos do inseticida; a meia vida deles em grãos foi de seis meses.

Maciel et al. (1993) trataram grãos de trigo com 7,5 e $15 \mathrm{mg} \cdot \mathrm{kg}^{-1}$ de fenitrotion, dos quais foi obtida posteriormente a farinha. Os tratamentos apresentaram resíduos na 
farinha de 2,1 e 3,0 mg.kg-1 , respectivamente, 1 dia após o tratamento e de 0,15 e 0,39 mg.kg-1 90 dias após.

Segundo Webley (1994), os resíduos encontrados em germe de trigo variam de acordo com a natureza do inseticida, sendo esta a ordem crescente deles: piretróides halogenados $<$ bioresmetrina $<$ fenotrina $<$ organofosforados $<$ metoprene. $\mathrm{O}$ autor encontrou concentração de $320 \%$ no farelo e redução de $25-32 \%$ nos níveis de deltametrina, após a operação de cozimento do pão.

Ong et al. (1994) obtiveram uma eficiência de aplicação em torno de 40\% para deltametrina em milho, sendo que três meses após o tratamento houve redução de $50 \%$ dos resíduos do referido inseticida.

Segundo dados da FAO, citados por Holland et al. (1994), a redução de resíduos durante o processamento de grãos de trigo, contendo deltametrina, é em média de 29, 91 , 69 e $94 \%$ para farinha integral, farinha branca, pão integral e pão branco respectivamente, no caso do farelo houve uma concentração da ordem de 3,3 vezes do valor encontrado no grão.

Jermannaud \& Pochon (1994) relatam que em ensaios realizados com trigo, em diversos países, a eficiência de aplicação de deltametrina variou de 10 a $68 \%$, sendo as perdas possivelmente devido ao contato da calda com outras superficies ou as gotas serem levadas por deriva para longe dos grãos. Os resíduos em farinha variaram de $<4$ a $45 \%$ dos valores encontrados nos grãos, sendo a presença do inseticida na mesma, possivelmente decorrente de contaminação durante o processo de moagem por contato com o farelo. Para farinha integral e farelo houve uma concentração de 0,84 e de 2,6 a 
5,3 em relação aos resíduos do piretróide encontrados nos grãos. As perdas durante o cozimento de diferentes tipos de pães variaram de 0 a $70 \%$.

Após o processamento de grãos de milho, tratados com deltametrina na formulação pó, para a obtenção de fubá, angu e bolinho, Peixoto et al. (1995a) observaram que não houve redução dos resíduos para os dois primeiros, sendo observada uma leve redução nos níveis do inseticida na preparação do bolinho, provavelmente devido a alta temperatura, $200^{\circ} \mathrm{C}$, a qual esse produto foi preparado.

Alleoni (1995), aplicando dosagens intencionais de 0,5 e $1,0 \mathrm{mg} \cdot \mathrm{kg}^{-1}$ de deltametrina em grãos de milho, obteve recuperação de 90 e $85 \%$, respectivamente e meia vida de 107 dias para ambas as dosagens.

Em experimentos com espigas de milho tratadas com $1 \mathrm{mg} \cdot \mathrm{kg}^{-1}$ de deltametrina na formulação pó, Peixoto et al. (1995b) estudaram os níveis de resíduo desse piretróide nos grãos, palhada e rolão de milho. Os autores não detectaram a ocorrência do inseticida nos grãos, sendo que para o rolão e a palhada os níveis residuais foram de 0,29 a 0,62 e 1,02 a $3,15 \mathrm{mg} \cdot \mathrm{kg}^{-1}$, respectivamente.

Skerritt et al. (1996), testando cinco diferentes dosagens de permetrina e bioresmetrina obtiveram depósito em grãos de trigo de $60-80 \%$ e $75-100 \%$ em relação a concentração pretendida. Após a moagem dos grãos, constatou-se uma concentração de 270 e $320 \%$ de bioresmetrina e permetrina no farelo, sendo que na farinha, obtida com $75 \%$ de extração, houve redução para 20 e $40 \%$ do depósito inicial, para os produtos acima referidos. 
O Quadro 1 apresenta os limites máximos de resíduos de alguns inseticidas, utilizados para controle de pragas em produtos armazenados, em produtos processados a partir de grãos de cereais, de acordo com o Codex Alimentarius da FAO (1998). 
Quadro 1. Limites máximos de resíduos de defensivos agrícolas em produtos processados de grãos armazenados.

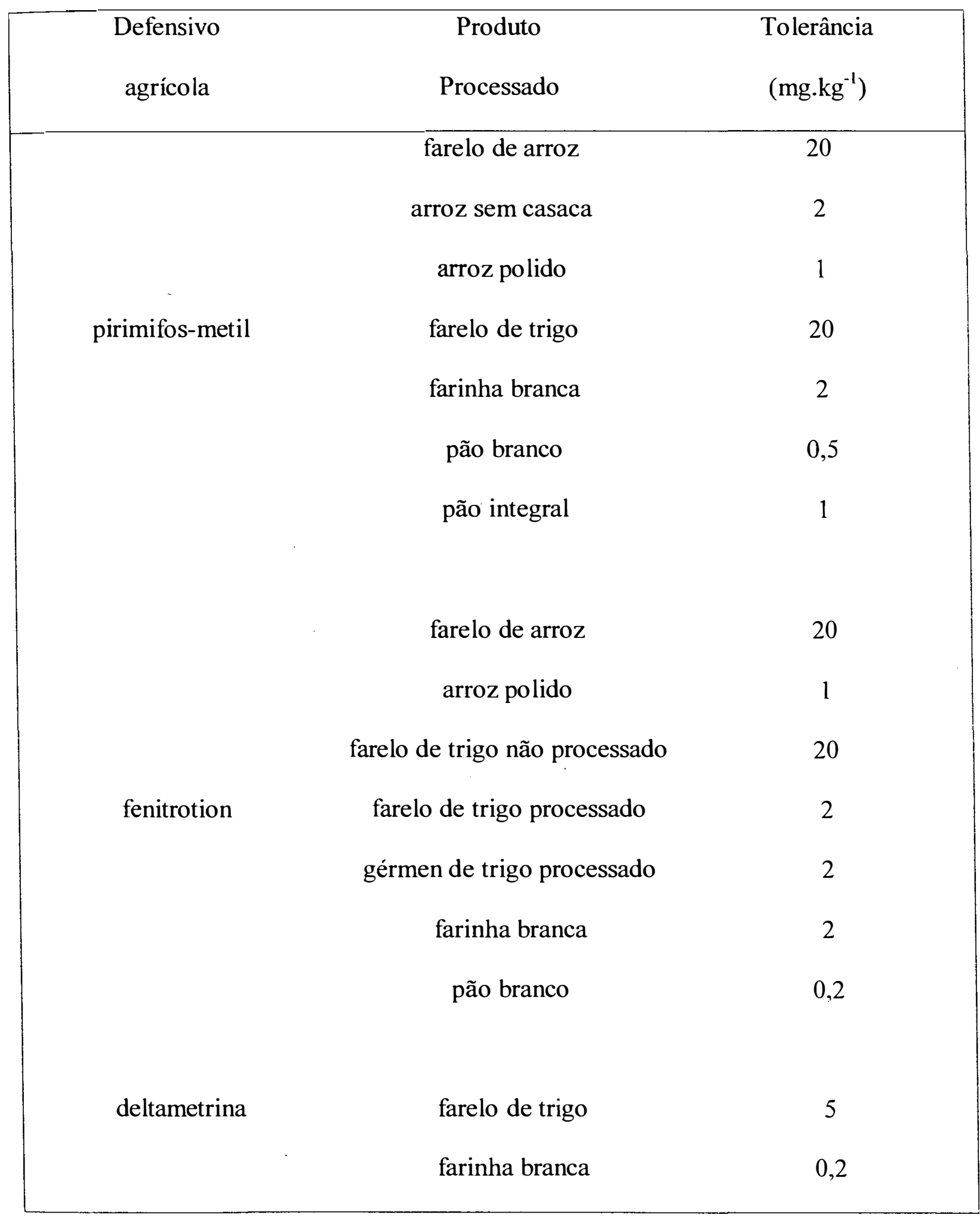




\section{MATERIAL E MÉTODOS}

\subsection{Experimentos de degradação e persistência dos resíduos de deltametrina}

Os experimentos foram desenvolvidos no setor de Toxicologia de Inseticidas do Departamento de Entomologia da Escola Superior de Agricultura "Luiz de Queiroz", da Universidade de São Paulo, em Piracicaba, com a colaboração de algumas empresas do setor alimentício.

Foram utilizados três tipos de grãos e alguns de seus produtos processados, a saber:

- grão de trigo, farinha integral, farinha branca, farelo de trigo e pão;

- grão de milho, milho canjicado, farelinho, farinha de milho ( biju ) e farelo de milho;

- grão de milho pipoca e pipoca.

A deltametrina foi aplicada de modo a produzir concentração teórica de 0,35 mg.kg-1 nos grãos. O delineamento experimental foi inteiramente ao acaso, com três repetições e os resíduos avaliados por período de 90 dias após o tratamento. O produto comercial utilizado foi o K-Obiol $25 \mathrm{CE}$ (25g de deltametrina $+250 \mathrm{~g}$ de PBO/litro).

A aplicação foi realizada com um pulverizador costal mantido a pressão constante com $\mathrm{CO}_{2}$, utilizando-se $300 \mathrm{ml}$ de emulsão inseticida (diluição 1:250 do produto comercial em água) para cada $60 \mathrm{~kg}$ de grãos (5L/ton.). Para cada operação de 
tratamento, os grãos foram acomodados e esparramados em fina camada sobre lençol plástico; após a aplicação, os grãos foram melhor misturados agitando-se-os com o auxílio de um rodo. Após o tratamento os grãos foram recolhidos em sacos plásticos pretos e armazenados sob balcão de laboratório.

As amostragens de grãos foram realizadas com zero, 15, 30, 60 e 90 dias após a aplicação, sendo, igualmente, destinadas amostras para processamento e obtenção de seus produtos processados. Estas, destinadas ao processamento, foram encaminhadas às unidades processadoras de empresas do setor alimentício onde foram preparadas.

Para o acompanhamento das condições dos grãos, foram mensalmente feitas análises de umidade deles, no Setor de Sementes do Departamento de Agricultura da ESALQ/USP, e coleta diária de dados de temperatura e umidade do local de armazenamento.

Os dados de umidade dos grãos eram obtidos pelo método da estufa $\left(105^{\circ} \mathrm{C}\right.$ por $24 \mathrm{~h}$ ), sendo cada medição realizada em duplicada e as amostras coletadas dos materiais tratados com o inseticida.

O total de amostras analisadas foi 240 , a saber: 1 inseticida $\times 1$ dosagem $\times 12$ substratos $\times 3$ repetições $\times 5$ períodos com total de 180, além de 60 amostras testemunha.

\subsection{Processamento dos grãos}

\subsubsection{Trigo}

O processamento do trigo foi realizado no Laboratório de Controle de Qualidade da Cargill Agrícola S.A., localizado no Município de Tatuí - SP. As amostras eram condicionadas a uma quantidade de água suficiente para elevar a umidade dos grãos até 15,5\%, sendo, ao depois, levadas para a moagem em um moinho da marca Chopin, 
modelo CD 1, o qual fornecia a farinha branca, mistura farinha/farelo e o farelo, sendo a farinha integral obtida a partir da mistura desses três componentes na proporção de $85 / 7,5 / 7,5$ respectivamente. O pão foi feito de modo caseiro utilizando-se farinha branca e integral, água, fermento, gordura vegetal e açúcar, sendo a massa cozida a temperatura de $\pm 200^{\circ} \mathrm{C}$ durante \pm 40 minutos.

\subsubsection{Milho}

As amostras de milho foram levadas até o Departamento de Agricultura da ESALQ/USP, onde, com o auxílio de uma canjiqueira, obtinha-se a canjica e o farelo de milho, sendo a primeira levada até a Fecularia Santa Teresinha, no município de Piracicaba - SP, e onde era deixada em imersão em água, a qual era renovada diariamente, durante 3 dias, para a obtenção do farelinho e do biju.

\subsubsection{Pipoca}

A pipoca foi obtida através da colocação dos grãos em sacos de pipoca para microondas comprados em supermercados, e depois esvaziados de seu conteúdo. Após condicionados na embalagem os grãos eram colocados em forno microondas na potência máxima durante 6 minutos.

3.3 Limites de quantificação, porcentagens de recuperação e métodos de análise de resíduos

Para o estudo dos limites de quantificação e porcentagens de recuperação dos resíduos do inseticida em grãos e seus produtos processados, amostras foram 
fortificadas, de modo a se obter concentrações nos níveis de 1,$0 ; 0,1 ; 0,05 ; 0,02 ; 0,01 \mathrm{e}$ $0,005 \mathrm{mg} \cdot \mathrm{kg}^{-1}$, em duplicata, e preparadas para análises de igual maneira às destinadas aos estudos de degradação e de persistência.

A determinação quantitativa foi feita por técnica de cromatografia em fase gasosa, usando-se aparelho equipado com detector de captura de elétrons (micro-ECD, $\left.\mathrm{Ni}^{63}\right)$.

\subsubsection{Método de análises de resíduos de deltametrina em grãos cereais e seus produtos processados}

O método de análise, adaptado a partir de L'Hotellier (1983), consta da extração dos resíduos das amostras com uma mistura de hexano + éter etílico. A limpeza do extrato é feita com partição de hexano e acetonitrilo, e coluna cromatográfica de sílica, sendo a eluição procedida com uma mistura de hexano + éter etílico; segue-se determinação quantitativa em cromatógrafo de gás equipado com ECD.

\subsubsection{Reagentes}

Para as determinações mencionadas, foram empregados os seguintes reagentes:

- acetonitrilo - PA; Merck, 17;

- éter etílico - PA, QM, 13342;

- hexano - AR, Malinckrodt, 5189;

- $\mathrm{Na}_{2} \mathrm{SO}_{4}$ anidro - Reagen, 10150 ;

- sílica gel - Merck, 7734;

- padrão analítico de deltametrina. 


\subsubsection{Aparelhos, vidrarias e outros materiais.}

Foram utilizados:

- cromatógrafo a gás, HP, modelo 6890, equipado com detector de captura de elétrons (micro-ECD, $\mathrm{Ni}^{63}$ );

- Integrador Varian 4400;

- coluna cromatográfica megabore J\&W DB-1 de 5 m de comprimento, diâmetro de $0,53 \mathrm{~mm}$ e $1,5 \mu \mathrm{m}$ de espessura do filme.

- manifold;

- chapa quente, Quimis;

- moinho de laboratório, Marte;

- mesa agitadora orbital, Marconi;

- balança analítica, Mettler H10;

- balança analítica, Sartorius Basic;

- microseringa - $10 \mu \mathrm{l}$, Hamilton;

- centrífuga Revan;

- frascos com tampa rosqueável de $100 \mathrm{ml}$, Duran-Schott;

- tubos de centrífuga de $50 \mathrm{ml}$, Corning 25330-50;

- tubos de centrífuga de 15 ml, Pyrex 8080;

- seringas hipodérmicas plásticas de $10 \mathrm{ml}, \mathrm{B}-\mathrm{D}$;

- provetas graduadas de 25 e $50 \mathrm{ml}$;

- pipetas graduadas de 1, 5 e $10 \mathrm{ml}$;

- pipetas volumétricas de 5,10 e $25 \mathrm{ml}$;

- pipeta Pipetman, Gilson P10 ml;

- EM-dispenser, Hirschmann 5-30 ml;

- erlenmeyer de $250 \mathrm{ml}$. Pyrex 5020;

- funil de Buchner, 100 mm de diâmetro, Chiaroti;

- papel de filtro $90 \mathrm{~mm}$ de diâmetro, Covadis;

- becker de $150 \mathrm{ml}$, Pyrex 1000;

- ultra-som, mini-som; 
- espátulas;

- vidro âmbar de $15 \mathrm{ml}$ com tampa.

\subsubsection{Marcha analítica}

\section{a) Extração}

a.1) Pesar $10 \mathrm{~g}$ da amostra ( $5 \mathrm{~g}$ para a pipoca), colocar em tubo Schott, juntar 50 $\mathrm{ml}$ de uma mistura de hexano + éter etílico $(1 / 1 \mathrm{v} / \mathrm{v})$ e deixar em agitação na mesa agitadora durante 15 minutos a $360 \mathrm{rpm}$;

a.2) Centrifugar a $2.500 \mathrm{rpm}$ por 5 minutos para separar as fases sólida da líquida; no caso da pipoca filtrar o extrato em funil de Buchner através de papel de filtro para um erlenmeyer;

a.3) Transferir para tubo de centrífuga de $50 \mathrm{ml}$, uma alíquota de $25 \mathrm{ml}$ do sobrenadante, sendo essa de $15 \mathrm{ml}$ para pipoca;

a.4) Evaporar totalmente os solventes contidos nos tubos de centrífuga com auxílio de ar movente em manifold e banho maria.

\section{b) Limpeza}

b.1) Adicionar aos tubos de centrífuga $10 \mathrm{ml}$ de hexano saturado em acetonitrilo e $25 \mathrm{ml}$ de acetonitrilo saturado em hexano e agitar por um minuto.

b.2) Centrifugar a $2.500 \mathrm{rpm}$ durante $3 \mathrm{~min}$.

b.3) Coletar da fase inferior uma alíquota de $5 \mathrm{ml}$, para grãos ( trigo, milho e pipoca ), farinhas ( branca e integral), farelos ( trigo e milho), pão e pipoca, ou de $10 \mathrm{ml}$, para canjica, farelinho e biju, em tubos de centrifuga de $15 \mathrm{ml}$. 
b.4) Evaporar completamente o conteúdo dos tubos com auxílio de ar movente em manifold e banho maria.

b.5) Ressuspender os extratos em $5 \mathrm{ml}$ de hexano e deixar no ultra-som por 1 minuto.

b.6) Preparar coluna cromatográfica a partir de seringa de $10 \mathrm{ml}$ da seguinte maneira: colocar algodão no fundo dela, da qual foi retirado o êmbolo, adicionar $1 \mathrm{~g}$ de sílica gel acrescentando, no topo, $0,2 \mathrm{~g}$ de $\mathrm{Na}_{2} \mathrm{SO}_{4}$ e por ultimo uma camada de algodão.

b.7) Pré-umidecer a coluna com $5 \mathrm{ml}$ de hexano.

b.8) Transferir o conteúdo de b.5 para a coluna e descartar todo o eluado.

b.9) Eluir a coluna com $10 \mathrm{ml}$ da mistura de hexano + éter etílico ( $9 / 1 \mathrm{v} / \mathrm{v})$, recolhendo os eluados em tubos de centrífuga de $15 \mathrm{ml}$.

b.10) Evaporar com auxílio de manifold, até secar.

\section{c) Determinação quantitativa}

c.1) Ressuspender os resíduos provenientes de b.10, até volume conveniente, com hexano e deixar no ultra-som por 1 minuto;

c.2) Injetar alíquotas no cromatógrafo.

c.3) Condições de operação do cromatógrafo:

Temperaturas:

coluna $=255^{\circ} \mathrm{C}$

vaporizador $=250^{\circ} \mathrm{C}$

detector $=300^{\circ} \mathrm{C}$

Fluxo de $\mathrm{N}_{2}$ :

coluna: $12,5 \mathrm{ml} / \mathrm{min}$

make up: $60 \mathrm{ml} / \mathrm{min}$

purge flow: $20 \mathrm{ml} / \mathrm{min}$

Purge time: $0,75 \mathrm{~min}$

Range: 5 
Atenuação de saída: 128 vezes

Tempo de retenção: 2 min. $05 \mathrm{seg}$.

\section{d) Cálculo dos resíduos}

Os resíduos são calculados por comparação direta com os padrões, baseados nas massas dos padrões analíticos e amostras.

$$
\text { ppm }=m g \cdot \mathrm{kg}^{-1}=\frac{m p \times m a m}{m p \times \text { Mam }}, \text { onde: }
$$

$\mathrm{mp}=$ massa injetada do padrão em pg;

mam = massa observada da substância na amostra, em pg, obtida por processamento do cromatograma pelo integrador;

Mp = massa observada da substância no padrão, em pg, obtida, igualmente, por processamento do cromatograma pelo integrador;

Mam $=$ Massa da amostra injetada em $\mu \mathrm{g}$. 


\section{RESULTADOS E DISCUSSÃO}

\subsection{Resíduos de deltametrina em grãos de trigo e em seus produtos processados}

Os resultados obtidos das análises de grãos de trigo e de seus produtos processados feitas a zero, 15, 30, 60 e 90 dias após a aplicação, são apresentados nas tabelas $1,2,3,4$ e 5 .

$\mathrm{Na}$ tabela 1 observa-se que da dosagem intencional de $0,35 \mathrm{mg} \cdot \mathrm{kg}^{-1}$ de deltametrina, recuperou-se, ao zero dia após a aplicação, $0,24 \mathrm{mg} \cdot \mathrm{kg}^{-1}$, ou seja, $69 \%$ da dosagem pretendida. Noble et al. (1982) recuperaram em média 102\% da deltametrina aplicada em grãos de trigo com umidades de 12 e 15\%, sendo que Jermannaud \& Pochon (1994) mostram variações de 10 a 68\% resultantes de experimentos realizados em diversos paises.

A alta recuperação obtida por Noble et al. (1982) deve-se, provavelmente, ao fato dos autores terem utilizado uma massa pequena de grãos e feito a aplicação em condições de laboratório, tendo os últimos relatado condições em que os tratamentos foram realizados de maneira comercial e tratadas quantidades grandes de grãos, mais próxima portanto da metodologia aqui empregada.

A análise conjunta das tabelas mostra, uma persistência e estabilidade bastante evidentes nos grãos armazenados, ao longo do período de estudos (90 dias), com variações de 0,22 a $0,27 \mathrm{mg} \cdot \mathrm{kg}^{-1}$.

A deltametrina mostrou tendência de se concentrar nas partes mais externas e oleosas do grão, pericarpo e gérmen, e em menor escala no endosperma, resultando uma 
concentração do inseticida da ordem de 2,12 vezes no farelo e redução média de $52,4 \%$ na farinha branca e $42,4 \%$ na integral. Se comparado com os resíduos contidos nos grãos, o pão integral mostrou redução de $84,6 \%$ nos níveis residuais sendo esta de $69 \%$ quando comparado com as farinhas usadas na sua produção. Schesse et al. (1958), usando metoxicloro, malation e lindane, Bazzi et al. (1972) com malation, Kadoum et al. (1978), utilizando malation, bromofós, iodofenfós e pirimifós-metil, Alnaji et al. (1979) com foxim metil, Bengston et al. (1980), usando pirimifós-metil, fenotrina, carbaril e fenitrotion, Visweswaraiah et al. (1991) com fenitrotion, PapadopoulouMorkidou (1991), Brown (1991) e Pucceti et al. (1993) com pirimifós-metil, Maciel et al. (1994) com fenitrotion, Webley (1994) com permetrina, bioresmetrina, metoprene e alguns organofosforados e Skerrit et al. (1996) com permetrina e bioresmetrina obtiveram redução desses inseticidas na farinha branca e/ou integral e em pães, sendo que no farelo houve concentração dos mesmos.

As concentrações de deltametrina encontradas no farelo e farinhas (branca e/ou integral), diferem daquelas encontradas por Bengston et al. (1983), de 4,6 vezes no farelo e de 0,24 na farinha branca; de Holland et al. (1994) de 3,3 vezes a concentração do piretróide no farelo e de 0,71, 0,09,0,31 e 0,06 nas farinhas (integral e branca) e pães (integral e branco) e também daqueles de L'Hotellier (1983) de 4 a 7 vezes para o farelo e 0,37 para a farinha branca, mas estão em conformidade com os valores citados por Jermannaud \& Pochon (1994), de 2,6 a 5,3 vezes para o farelo, 0,84 para a farinha integral e de $<0,04$ a 0,45 para a farinha branca.

Pode-se supor que essas diferenças sejam decorrentes da metodologia e do tipo e/ou modelo de moinho usado para se obter as frações moídas do grão de trigo, bem como, uma diferença entre variedades, resultando assim em diferentes níveis de absorção do inseticida para as partes mais internas do grão, como os resultados obtidos por McGaughey (1971), em que as variedades de arroz que possuíam uma casca menos espessa apresentavam penetração mais intensa de malation para o interior do grão.

O maior nivel de resíduo encontrado na farinha branca, e consequentemente o menor encontrado no farelo, em relação a outros trabalhos, pode ainda estar relacionado à uma absorção do inseticida pelo endosperma durante o processo de condicionamento 
à uma absorção do inseticida pelo endosperma durante o processo de condicionamento dos grãos para aumento de umidade, já que Cogburn et al. (1990) observaram que o arroz parbolizado continha uma quantidade maior de malation e de clorpirifós nas suas frações mais internas do que o arroz não parbolizado.

Com relação aos dados de degradação dos resíduos de deltametrina após o cozimento da massa do pão, Bengston et al. (1983) relatam não ter ocorrido perdas do piretróide após essa operação; L'Hotellier (1983) considera que as perdas foram aparentes, devido a diluição do inseticida pela adição de água na composição do pão. Joia et al. (1985) registraram perdas de 21 e 13\% de cipermetrina e fenvalerato para o pão integral a partir de sua farinha; Jermannaud \& Pochon (1994) relatam perdas variáveis de 0 a 70\%, para diversos tipos de pães, sendo que para Holland et al. (1994) houve variações de 58 a 99\% de perdas, ainda Peixoto et al. (1995a) obtiveram perdas de $15 \%$ após o cozimento de bolinhos de milho a partir de uma massa feita com fubá de milho.

Provavelmente as variações de resíduos de deltametrina nos diversos trabalhos, devem-se às diferentes receitas de pães, podendo variar a quantidade de água utilizada e a temperatura de cozimento. No experimento aqui descrito pode-se citar como fatores da diminuição do nível residual de deltametrina no pão, a sua maior umidade em relação as farinhas e a temperatura de cozimento, de $\pm 200{ }^{\circ} \mathrm{C}$ durante 40 minutos, já que temperaturas acima de $190{ }^{\circ} \mathrm{C}$ acarretam perdas significantes deste piretróide (Tessier, 1983).

Os resíduos encontrados nos grãos de trigo, bem como nos de milho e milho pipoca, tratados com a dosagem intencional de $0,35 \mathrm{mg} \mathrm{kg}^{-1}$, mostraram-se, obviamente, bem menores do que a tolerância estabelecida pela legislação brasileira, de $1 \mathrm{mg} \cdot \mathrm{kg}^{-1}$, para grãos armazenados. A indicação agronômica $\left(0,35 \mathrm{mg} \cdot \mathrm{kg}^{-1}\right)$ comparada à tolerância legal ( $1 \mathrm{mg} \cdot \mathrm{kg}^{-1}$ ), a princípio, permite o consumo dos grãos logo após o tratamento; isto indica que a legislação pertinente necessita ser coerentemente adequada ao uso do inseticida em grãos armazenados.

Para os produtos obtidos através da moagem de grãos de trigo não se tem dados sobre os limites máximos de resíduos na legislação nacional, necessitando-se, para fins 
comparativos, fazer uso dos dados fornecidos pelo Codex Alimentarius da FAO (1998), onde tem-se como sendo de 5 e $0,2 \mathrm{mg} \cdot \mathrm{kg}^{-1}$ a tolerância para farelo e farinha branca de trigo. Apesar de ser atualmente o mais importante inseticida para grãos armazenados, os dados sobre tolerância em produtos derivados de grãos armazenados deixam a desejar em relação a outros produtos, uma vez que já se os têm em maiores freqüências para tais inseticidas como fenitrotion e pirimifós-metil. 
Tabela 1. Resíduos de deltametrina em grãos de trigo, tratados com $0,35 \mathrm{mg} \cdot \mathrm{kg}^{-1}$ do inseticida, e em seus produtos processados e concentração dos resíduos após cada etapa de beneficiamento, zero dia após aplicação.

\begin{tabular}{|c|c|c|c|c|c|c|}
\hline \multirow{2}{*}{ Tratamento } & \multirow{2}{*}{ Substrato } & \multicolumn{3}{|c|}{ Repetições } & Média & Indice de \\
\hline & & a & b & c & $m+s$ & dos resíduos \\
\hline
\end{tabular}

\begin{tabular}{lllllll} 
& grão de trigo & 0,23 & 0,26 & 0,24 & $0,24 \pm 0,02$ & 1 \\
& farinha branca & 0,10 & 0,14 & 0,16 & $0,13 \pm 0,03$ & 0,54 \\
grão tratado & farinha integral & 0,15 & 0,19 & 0,15 & $0,16 \pm 0,02$ & 0,67 \\
& pão integral & 0,06 & 0,07 & 0,07 & $0,07 \pm 0,003$ & 0,29 \\
& farelo de trigo & 0,55 & 0,59 & 0,56 & $0,57 \pm 0,02$ & 2,39 \\
\hline \multirow{5}{*}{ testemunha } & & & & & \\
& grão de trigo & $<0,01$ & $<0,01$ & $<0,01$ & $<0,01$ & - \\
& farinha branca & $<0,01$ & $<0,01$ & $<0,01$ & $<0,01$ & - \\
& pão integral & $<0,01$ & $<0,01$ & $<0,01$ & $<0,01$ & - \\
& farelo de trigo & $<0,05$ & $<0,05$ & $<0,05$ & $<0,05$ & - \\
\hline \hline
\end{tabular}

$\mathrm{m}=$ média

$\mathrm{s}=$ desvio padrão da média 
Tabela 2. Resíduos de deltametrina em grãos de trigo, tratados com $0,35 \mathrm{mg} \cdot \mathrm{kg}^{-1}$ do inseticida, e em seus produtos processados e concentração dos resíduos após cada etapa de beneficiamento, 15 dias após aplicação.

\begin{tabular}{|c|c|c|c|c|c|c|}
\hline \multirow{2}{*}{ Tratamento } & \multirow{2}{*}{ Substrato } & \multicolumn{3}{|c|}{ Repetições } & \multirow{2}{*}{$\begin{array}{c}\text { Média } \\
\left(\mathrm{mg} \cdot \mathrm{kg}^{-1}\right) \\
\mathrm{m} \pm \mathrm{s}\end{array}$} & \multirow{2}{*}{$\begin{array}{c}\text { Indice de } \\
\text { concentração } \\
\text { dos resíduos }\end{array}$} \\
\hline & & $\mathrm{a}$ & b & $\mathrm{c}$ & & \\
\hline \multirow{5}{*}{ grão tratado } & grão de trigo & 0,27 & 0,24 & 0,28 & $0,27 \pm 0,02$ & 1 \\
\hline & farinha branca & 0,11 & 0,11 & 0,11 & $0,11 \pm 0,00$ & 0,41 \\
\hline & farinha integral & 0,16 & 0,17 & 0,16 & $0,16 \pm 0,01$ & 0,59 \\
\hline & pão integral & 0,04 & 0,04 & 0,03 & $0,04 \pm 0,004$ & 0,15 \\
\hline & farelo de trigo & 0,60 & 0,61 & 0,58 & $0,60 \pm 0,02$ & 2,22 \\
\hline \multirow{5}{*}{ testemunha } & grão de trigo & $<0,01$ & $<0,01$ & $<0,01$ & $<0,01$ & - \\
\hline & farinha branca & $<0,01$ & $<0,01$ & $<0,01$ & $<0,01$ & - \\
\hline & farinha integral & $<0,01$ & $<0,01$ & $<0,01$ & $<0,01$ & - \\
\hline & pão integral & $<0,01$ & $<0,01$ & $<0,01$ & $<0,01$ & - \\
\hline & farelo de trigo & $<0,05$ & $<0,05$ & $<0,05$ & $<0,05$ & - \\
\hline
\end{tabular}

$\mathrm{m}=$ média

$\mathbf{s}=$ desvio padrão da média 
Tabela 3. Resíduos de deltametrina em grãos de trigo, tratados com $0,35 \mathrm{mg} \cdot \mathrm{kg}^{-1}$ do inseticida, e em seus produtos processados e concentração dos resíduos após cada etapa de beneficiamento, 30 dias após aplicação.

\begin{tabular}{|c|c|c|c|c|c|c|}
\hline \multirow{2}{*}{ Tratamento } & \multirow{2}{*}{ Substrato } & \multicolumn{3}{|c|}{ Repetições } & \multirow{2}{*}{$\begin{array}{c}\text { Média } \\
\left(\mathrm{mg} \cdot \mathrm{kg}^{-1}\right) \\
\mathrm{m} \pm \mathrm{s}\end{array}$} & \multirow{2}{*}{$\begin{array}{c}\text { Indice de } \\
\text { concentração } \\
\text { dos resíduos }\end{array}$} \\
\hline & & $\mathrm{a}$ & b & c & & \\
\hline \multirow{5}{*}{ grão tratado } & grão de trigo & 0,24 & 0,24 & 0,22 & $0,24 \pm 0,01$ & 1 \\
\hline & farinha branca & 0,10 & 0,10 & 0,10 & $0,10 \pm 0,00$ & 0,42 \\
\hline & farinha integral & 0,13 & 0,16 & 0,14 & $0,14 \pm 0,01$ & 0,58 \\
\hline & pão integral & 0,03 & 0,04 & 0,03 & $0,03 \pm 0,003$ & 0,13 \\
\hline & farelo de trigo & 0,55 & 0,58 & 0,56 & $0,56 \pm 0,01$ & 2,33 \\
\hline \multirow{5}{*}{ testemunha } & grão de trigo & $<0,01$ & $<0,01$ & $<0,01$ & $<0,01$ & - \\
\hline & farinha branca & $<0,01$ & $<0,01$ & $<0,01$ & $<0,01$ & - \\
\hline & farinha integral & $<0,01$ & $<0,01$ & $<0,01$ & $<0,01$ & - \\
\hline & pão integral & $<0,01$ & $<0,01$ & $<0,01$ & $<0,01$ & - \\
\hline & farelo de trigo & $<0,05$ & $<0,05$ & $<0,05$ & $<0,05$ & - \\
\hline
\end{tabular}

$\mathrm{m}=$ média

$\mathbf{s}=$ desvio padrão da média 
Tabela 4. Resíduos de deltametrina em grãos de trigo, tratados com $0,35 \mathrm{mg} \cdot \mathrm{kg}^{-1}$ do inseticida, e em seus produtos processados e concentração dos resíduos após cada etapa de beneficiamento, 60 dias após aplicação.

\begin{tabular}{|c|c|c|c|c|c|c|}
\hline \multirow{2}{*}{ Tratamento } & \multirow{2}{*}{ Substrato } & \multicolumn{3}{|c|}{ Repetições } & \multirow{2}{*}{$\begin{array}{c}\text { Média } \\
\left(\mathrm{mg}^{\left.-\mathrm{kg}^{-1}\right)}\right. \\
\mathrm{m} \pm \mathrm{s}\end{array}$} & \multirow{2}{*}{$\begin{array}{c}\text { Índice de } \\
\text { concentração } \\
\text { dos resíduos }\end{array}$} \\
\hline & & $\mathrm{a}$ & b & c & & \\
\hline \multirow{5}{*}{ grão tratado } & grão de trigo & 0,27 & 0,27 & 0,25 & $0,26 \pm 0,01$ & 1 \\
\hline & farinha branca & 0,10 & 0,10 & 0,12 & $0,11 \pm 0,01$ & 0,42 \\
\hline & farinha integral & 0,13 & 0,13 & 0,13 & $0,13 \pm 0,00$ & 0,50 \\
\hline & pão integral & 0,03 & 0,03 & 0,03 & $0,03 \pm 0,00$ & 0,12 \\
\hline & farelo de trigo & 0,42 & 0,43 & 0,43 & $0,43 \pm 0,01$ & 1,65 \\
\hline \multirow{5}{*}{ testemunha } & grão de trigo & $<0,01$ & $<0,01$ & $<0,01$ & $<0,01$ & - \\
\hline & farinha branca & $<0,01$ & $<0,01$ & $<0,01$ & $<0,01$ & - \\
\hline & farinha integral & $<0,01$ & $<0,01$ & $<0,01$ & $<0,01$ & - \\
\hline & pão integral & $<0,01$ & $<0,01$ & $<0,01$ & $<0,01$ & - \\
\hline & farelo de trigo & $<0,05$ & $<0,05$ & $<0,05$ & $<0,05$ & - \\
\hline
\end{tabular}

$\mathrm{m}=$ média

$\mathrm{s}=$ desvio padrão da média 
Tabela 5. Resíduos de deltametrina em grãos de trigo, tratados com $0,35 \mathrm{mg} \cdot \mathrm{kg}^{-1}$ do inseticida, e em seus produtos processados e concentração dos resíduos após cada etapa de beneficiamento, 90 dias após aplicação.

\begin{tabular}{|c|c|c|c|c|c|c|}
\hline \multirow{2}{*}{ Tratamento } & \multirow{2}{*}{ Substrato } & \multicolumn{3}{|c|}{ Repetições } & \multirow{2}{*}{$\begin{array}{c}\text { Média } \\
\left(\mathrm{mg} \cdot \mathrm{kg}^{-1}\right) \\
\mathrm{m} \pm \mathrm{s}\end{array}$} & \multirow{2}{*}{$\begin{array}{c}\text { Indice de } \\
\text { concentração } \\
\text { dos resíduos }\end{array}$} \\
\hline & & $\mathrm{a}$ & b & c & & \\
\hline \multirow{5}{*}{ grão tratado } & grão de trigo & 0,22 & 0,24 & 0,22 & $0,22 \pm 0,01$ & 1 \\
\hline & farinha branca & 0,10 & 0,10 & 0,09 & $0,09 \pm 0,006$ & 0,41 \\
\hline & farinha integral & 0,12 & 0,13 & 0,13 & $0,12 \pm 0,008$ & 0,54 \\
\hline & pão integral & 0,02 & 0,02 & 0,02 & $0,02 \pm 0,001$ & 0,10 \\
\hline & farelo de trigo & 0,43 & 0,43 & 0,46 & $0,44 \pm 0,02$ & 2,00 \\
\hline \multirow{5}{*}{ Testemunha } & grão de trigo & $<0,01$ & $<0,01$ & $<0,01$ & $<0,01$ & - \\
\hline & farinha branca & $<0,01$ & $<0,01$ & $<0,01$ & $<0,01$ & - \\
\hline & farinha integral & $<0,01$ & $<0,01$ & $<0,01$ & $<0,01$ & - \\
\hline & pão integral & $<0,01$ & $<0,01$ & $<0,01$ & $<0,01$ & - \\
\hline & farelo de trigo & $<0,05$ & $<0,05$ & $<0,05$ & $<0,05$ & - \\
\hline
\end{tabular}

$$
\begin{aligned}
& \mathrm{m}=\text { média } \\
& \mathrm{s}=\text { desvio padrão da média }
\end{aligned}
$$




\subsection{Resíduos de deltametrina em grãos de milho e em seus produtos processados.}

Os resultados obtidos das análises de grãos de milho e de seus produtos processados feitas a zero, 15, 30, 60 e 90 dias após a aplicação, são apresentadas nas tabelas $6,7,8,9$ e 10 .

$\mathrm{Na}$ tabela 6 observa-se que da dosagem intencional de $0,35 \mathrm{mg} \cdot \mathrm{kg}^{-1}$ de deltametrina, recuperou-se, ao zero dia após a aplicação, $0,25 \mathrm{mg} \cdot \mathrm{kg}^{-1}$, ou seja, $71 \% \mathrm{da}$ concentração pretendida. Esse resultado fica entre os dados obtidos por Ong et al. (1994), que foi de $40 \%$ e os de Alleoni (1995), de 85 e $90 \%$, sendo os valores encontrados pelo últimos mais próximos aos obtidos no presente trabalho pelo fato da metodologia de aplicação ser semelhante.

A análise conjunta das tabelas mostra, uma persistência e estabilidade bastante evidentes nos grãos armazenados, ao longo do período de estudos (90 dias), com variações de 0,19 a $0.25 \mathrm{mg} \cdot \mathrm{kg}^{-1}$.

Após a moagem dos grãos de milho, verificou-se resíduos do inseticida somente no farelo, sendo que na maioria das análises de canjica, os resíduos, se presentes, eram menores do que o limite de quantificação do método, supondo-se assim, que a quase totalidade dos resíduos de deltametrina encontravam-se na camada externa do grão, pericarpo e gérmen, o que vem de acordo com os dados de Hall et al. (1973), em que a união pericarpo/gérmen encerrava 94 e 100\% dos resíduos de Gardona e diclorvós.

Não foi constatada a presença do inseticida no farelinho e no biju, mesmo porque, além de apenas duas amostras de canjica apresentarem resíduos detectáveis, esta foi condicionada durante 3 dias em água, o que possivelmente deve ter eliminado qualquer possibilidade da presença do piretróide no farelinho e no biju, já que Tejada et al. (1990) obtiveram reduções de 77 a 100\% nos resíduos de clorpirifós após três lavagens dos grãos de milho.

Em relação aos outros grãos analisados, o milho mostrou maior degradação durante o período do experimento, $24 \%$, em relação ao trigo ( $8 \%$ e milho pipoca $(0 \%)$, isso devido ao maior teor de umidade do primeiro em relação aos outros, o que está de 
acordo com os dados obtidos por Kadoum \& LaHue(1979), onde grãos com maior umidade resultaram em uma degradação mais rápida de malation.

Com respeito a tolerância de resíduos de deltametrina em produtos processados de milho, não existem dados na legislação nacional e nem no Codex Alimentarius da FAO (1998), mas de acordo com os dados obtidos nenhum dos derivados de grão de milho apresentou resíduos acima da tolerância determinada para grãos armazenados, ou seja, esses produtos poderiam, a princípio, ser consumidos imediatamente, não necessitando então observar-se o período de carência. 
Tabela 6. Resíduos de deltametrina em grãos de milho, tratados com $0,35 \mathrm{mg} \cdot \mathrm{kg}^{-1}$ do inseticida, e em seus produtos processados e concentração dos resíduos após cada etapa de beneficiamento, zero dia após aplicação.

\begin{tabular}{|c|c|c|c|c|c|c|}
\hline \multirow{2}{*}{ Tratamento } & \multirow{2}{*}{ Substrato } & \multicolumn{3}{|c|}{ Repetições } & \multirow{2}{*}{$\begin{array}{c}\text { Média } \\
\left(\mathrm{mg}^{\left.-k g^{-1}\right)}\right. \\
m \pm s\end{array}$} & \multirow{2}{*}{$\begin{array}{c}\text { Índice de } \\
\text { concentração } \\
\text { dos resíduos }\end{array}$} \\
\hline & & $\mathrm{a}$ & b & c & & \\
\hline \multirow{5}{*}{ grão tratado } & grão de milho & 0,27 & 0,23 & 0,25 & $0,25 \pm 0,02$ & 1 \\
\hline & canjica & 0,01 & $<0,01$ & $<0,01$ & 0,01 & - \\
\hline & farelinho & $<0,01$ & $<0,01$ & $<0,01$ & $<0,01$ & - \\
\hline & biju & $<0,01$ & $<0,01$ & $<0,01$ & $<0,01$ & - \\
\hline & farelo de milho & 0,92 & 0,90 & 0,89 & $0,90 \pm 0,02$ & 3,6 \\
\hline \multirow{5}{*}{ Testemunha } & grão de milho & $<0,02$ & $<0,02$ & $<0,02$ & $<0,02$ & - \\
\hline & canjica & $<0,01$ & $<0,01$ & $<0,01$ & $<0,01$ & - \\
\hline & farelinho & $<0,01$ & $<0,01$ & $<0,01$ & $<0,01$ & - \\
\hline & biju & $<0,01$ & $<0,01$ & $<0,01$ & $<0,01$ & - \\
\hline & farelo de milho & $<0,05$ & $<0,05$ & $<0,05$ & $<0,05$ & - \\
\hline
\end{tabular}

$$
\begin{aligned}
& \mathrm{m}=\text { média } \\
& \mathrm{s}=\text { desvio padrão da média }
\end{aligned}
$$


Tabela 7. Resíduos de deltametrina em grãos de milho, tratados com $0,35 \mathrm{mg} \cdot \mathrm{kg}^{-1}$ do inseticida, e em seus produtos processados e concentração dos resíduos após cada etapa de beneficiamento, 15 dias após aplicação.

\begin{tabular}{|c|c|c|c|c|c|c|}
\hline \multirow{2}{*}{ Tratamento } & \multirow{2}{*}{ Substrato } & \multicolumn{3}{|c|}{ Repetições } & \multirow{2}{*}{$\begin{array}{c}\text { Média } \\
\left(\mathrm{mg}^{\mathrm{kgg}}{ }^{-1}\right) \\
\mathrm{m} \pm \mathrm{s}\end{array}$} & \multirow{2}{*}{$\begin{array}{c}\text { Índice de } \\
\text { concentração } \\
\text { dos resíduos }\end{array}$} \\
\hline & & a & b & $\mathrm{c}$ & & \\
\hline \multirow{5}{*}{ grão tratado } & grão de milho & 0,22 & 0,19 & 0,21 & $0,21 \pm 0,02$ & 1 \\
\hline & canjica & $<0,01$ & $<0,01$ & $<0,01$ & $<0,01$ & - \\
\hline & farelinho & $<0,01$ & $<0,01$ & $<0,01$ & $<0,01$ & - \\
\hline & biju & $<0,01$ & $<0,01$ & $<0,01$ & $<0,01$ & - \\
\hline & farelo de milho & 0,79 & 0,80 & 0,88 & $0,83 \pm 0,05$ & 3,95 \\
\hline \multirow{5}{*}{ testemunha } & grão de milho & $<0,02$ & $<0,02$ & $<0,02$ & $<0,02$ & - \\
\hline & canjica & $<0,01$ & $<0,01$ & $<0,01$ & $<0,01$ & - \\
\hline & farelinho & $<0,01$ & $<0,01$ & $<0,01$ & $<0,01$ & - \\
\hline & biju & $<0,01$ & $<0,01$ & $<0,01$ & $<0,01$ & - \\
\hline & farelo de milho & $<0,05$ & $<0,05$ & $<0,05$ & $<0,05$ & - \\
\hline
\end{tabular}

$\mathrm{m}=$ média

$\mathrm{s}=$ desvio padrão da média 
Tabela 8. Resíduos de deltametrina em grãos de milho, tratados com $0,35 \mathrm{mg} \cdot \mathrm{kg}^{-1}$ do inseticida, e em seus produtos processados e concentração dos resíduos após cada etapa de beneficiamento, 30 dias após aplicação.

\begin{tabular}{|c|c|c|c|c|c|c|}
\hline \multirow{2}{*}{ Tratamento } & \multirow{2}{*}{ Substrato } & \multicolumn{3}{|c|}{ Repetições } & \multirow{2}{*}{$\begin{array}{c}\text { Média } \\
\left(\mathrm{mg} \cdot \mathrm{kg}^{-1}\right) \\
\mathrm{m} \pm \mathrm{s}\end{array}$} & \multirow{2}{*}{$\begin{array}{c}\text { Indice de } \\
\text { concentração } \\
\text { dos resíduos }\end{array}$} \\
\hline & & $\mathrm{a}$ & b & $\mathrm{c}$ & & \\
\hline \multirow{5}{*}{ grão tratado } & grão de milho & 0,22 & 0,21 & 0,21 & $0,21 \pm 0,01$ & 1 \\
\hline & canjica & $<0,01$ & 0,01 & $<0,01$ & 0,01 & - \\
\hline & farelinho & $<0,01$ & $<0,01$ & $<0,01$ & $<0,01$ & - \\
\hline & biju & $<0,01$ & $<0,01$ & $<0,01$ & $<0,01$ & - \\
\hline & farelo de milho & 0,77 & 0,73 & 0,73 & $0,74 \pm 0,02$ & 3,52 \\
\hline \multirow{5}{*}{ testemunha } & grão de milho & $<0,02$ & $<0,02$ & $<0,02$ & $<0,02$ & - \\
\hline & canjica & $<0,01$ & $<0,01$ & $<0,01$ & $<0,01$ & - \\
\hline & farelinho & $<0,01$ & $<0,01$ & $<0,01$ & $<0,01$ & - \\
\hline & biju & $<0,01$ & $<0,01$ & $<0,01$ & $<0,01$ & - \\
\hline & farelo de milho & $<0,05$ & $<0,05$ & $<0,05$ & $<0,05$ & - \\
\hline
\end{tabular}

$\mathrm{m}=$ média

$\mathrm{s}=$ desvio padrão da média 
Tabela 9. Resíduos de deltametrina em grãos de milho, tratados com $0,35 \mathrm{mg} \cdot \mathrm{kg}^{-1}$ do inseticida, e em seus produtos processados e concentração dos resíduos após cada etapa de beneficiamento, 60 dias após aplicação.

\begin{tabular}{ccccccc}
\hline \hline & & Repetições & & Média & Índice de \\
Tratamento & Substrato & & & & $\left(\mathrm{mg}^{\left.-k^{-1}\right)}\right.$ & concentração \\
& & a & b & c & $\mathrm{m} \pm \mathrm{s}$ & dos resíduos \\
\hline \hline
\end{tabular}

\begin{tabular}{llrrrlc} 
& grão de milho & 0,20 & 0,19 & 0,18 & $0,19 \pm 0,01$ & 1 \\
canjica & $<0,01$ & $<0,01$ & $<0,01$ & $<0,01$ & - \\
grão tratado & farelinho & $<0,01$ & $<0,01$ & $<0,01$ & $<0,01$ & - \\
& biju & $<0,01$ & $<0,01$ & $<0,01$ & $<0,01$ & - \\
farelo de milho & 0,58 & 0,58 & 0,60 & $0,59 \pm 0,01$ & 3,11 \\
\hline
\end{tabular}

\begin{tabular}{lllllll} 
grão de milho & $<0,02$ & $<0,02$ & $<0,02$ & $<0,02$ & - \\
canjica & $<0,01$ & $<0,01$ & $<0,01$ & $<0,01$ & - \\
testemunha & farelinho & $<0,01$ & $<0,01$ & $<0,01$ & $<0,01$ & - \\
& biju & $<0,01$ & $<0,01$ & $<0,01$ & $<0,01$ & - \\
farelo de milho & $<0,05$ & $<0,05$ & $<0,05$ & $<0,05$ & - \\
\hline \hline
\end{tabular}

$\mathrm{m}=$ média

$\mathbf{s}=$ desvio padrão da média 
Tabela 10. Resíduos de deltametrina em grãos de milho, tratados com $0,35 \mathrm{mg} \cdot \mathrm{kg}^{-1}$ do inseticida, e em seus produtos processados e concentração dos resíduos após cada etapa de beneficiamento, 90 dias após aplicação.

\begin{tabular}{|c|c|c|c|c|c|c|}
\hline \multirow{2}{*}{ Tratamento } & \multirow{2}{*}{ Substrato } & \multicolumn{3}{|c|}{$\overline{\text { Repetições }}$} & \multirow{2}{*}{$\begin{array}{c}\text { Média } \\
\left(\mathrm{mg} \cdot \mathrm{kg}^{-1}\right) \\
\mathrm{m} \pm \mathrm{s}\end{array}$} & \multirow{2}{*}{$\begin{array}{c}\text { Índice de } \\
\text { concentração } \\
\text { dos resíduos }\end{array}$} \\
\hline & & $\mathrm{a}$ & $\mathrm{b}$ & c & & \\
\hline \multirow{5}{*}{ grão tratado } & grão de milho & 0,20 & 0,18 & 0,20 & $0,19 \pm 0,01$ & 1 \\
\hline & canjica & $<0,01$ & $<0,01$ & $<0,01$ & $<0,01$ & - \\
\hline & farelinho & $<0,01$ & $<0,01$ & $<0,01$ & $<0,01$ & - \\
\hline & biju & $<0,01$ & $<0,01$ & $<0,01$ & $<0,01$ & - \\
\hline & farelo de milho & 0,61 & 0,59 & 0,59 & $0,60 \pm 0,01$ & 3,16 \\
\hline \multirow{5}{*}{ testemunha } & grão de milho & $<0,02$ & $<0,02$ & $<0,02$ & $<0,02$ & - \\
\hline & canjica & $<0,01$ & $<0,01$ & $<0,01$ & $<0,01$ & - \\
\hline & farelinho & $<0,01$ & $<0,01$ & $<0,01$ & $<0,01$ & - \\
\hline & biju & $<0,01$ & $<0,01$ & $<0,01$ & $<0,01$ & - \\
\hline & farelo de milho & $<0,02$ & $<0,02$ & $<0,02$ & $<0,02$ & - \\
\hline
\end{tabular}

$$
\begin{aligned}
& \mathrm{m}=\text { média } \\
& \mathrm{s}=\text { desvio padrão da média }
\end{aligned}
$$




\subsection{Resíduos de deltametrina em grãos de pipoca e em pipoca}

Os resultados obtidos das análises de grãos de milho pipoca e de seus produtos processados feitas a zero, 15, 30, 60 e 90 dias após a aplicação, são apresentados nas tabelas $11,12,13,14$ e 15 .

$\mathrm{Na}$ tabela 11 observa-se que da dosagem intencional de $0,35 \mathrm{mg} \cdot \mathrm{kg}^{-1}$ de deltametrina, recuperou-se ao zero dia após a aplicação $0,23 \mathrm{mg} \cdot \mathrm{kg}^{-1}$, ou seja, $68 \%$ da concentração pretendida.

A análise conjunta das tabelas mostra, uma persistência e estabilidade bastante evidentes nos grãos armazenados, ao longo do período de estudos (90 dias), com variações de 0,23 a $0,24 \mathrm{mg} \cdot \mathrm{kg}^{-1}$.

Após o preparo da pipoca, verificou-se uma concentração média de 1,58 vezes do inseticida, diferente de Singh \& Chawla (1980), que encontraram reduções de 77,1 e $81,9 \%$ nos resíduos de pirimifós-metil, provavelmente, devido a menor estabilidade do organofosforado em temperaturas elevadas e também por que, possivelmente, o saco de papel usado no preparo de pipoca em microondas impediu perdas por volatilização do piretróide.

O aumento da concentração de deltametrina, após o preparo da pipoca, é decorrente da menor umidade da mesma com relação ao grão (Tabelas 18 e 20) e também, à perdas durante o preparo das amostras de grãos, os quais precisaram ser transformados em fubá para serem analisados, sendo que Lockwood (1973) cita perdas de malation e fenitrotion variando de 30 a 70\%, após o processo de moagem do arroz, trigo e sorgo, devido ao aquecimento do moinho e L'Hotellier (1983), que após essa operação observou perdas médias de deltametrina em tomo de 15\% nos grãos moídos.

Como no caso do milho não se tem dados sobre o limite máximo de resíduos de deltametrina em pipoca, mas assim como nos produtos obtidos a partir do milho a pipoca não ultrapassou a tolerância nacional para grãos armazenados, sendo, seu consumo, a princípio, possível de ser feito imediatamente. 
Tabela 11. Resíduos de deltametrina em grãos de pipoca, tratados com $0,35 \mathrm{mg} \cdot \mathrm{kg}^{-1}$ do inseticida, e em seu produto processado e concentração dos resíduos após o beneficiamento, zero dia após aplicação.

\begin{tabular}{|c|c|c|c|c|c|c|}
\hline \multirow{2}{*}{ Tratamento } & \multirow{2}{*}{ Substrato } & \multicolumn{3}{|c|}{ Repetições } & \multirow{2}{*}{$\begin{array}{c}\text { Média } \\
\left(\mathrm{mg} \cdot \mathrm{kg}^{-1}\right) \\
\mathrm{m} \pm \mathrm{s}\end{array}$} & \multirow{2}{*}{$\begin{array}{c}\text { Indice de } \\
\text { concentração } \\
\text { dos resíduos }\end{array}$} \\
\hline & & $\mathrm{a}$ & b & c & & \\
\hline \multirow[t]{2}{*}{ grão tratado } & grão de pipoca & 0,21 & 0,23 & 0,24 & $0,23 \pm 0,02$ & 1 \\
\hline & pipoca & 0,39 & 0,48 & 0,42 & $0,43 \pm 0,05$ & 1,9 \\
\hline \multirow[t]{2}{*}{ testemunha } & grão de pipoca & $<0,02$ & $<0,02$ & $<0,02$ & $<0,02$ & - \\
\hline & pipoca & $<0,05$ & $<0,05$ & $<0,05$ & $<0,05$ & - \\
\hline
\end{tabular}

$\mathrm{m}=$ média

$\mathrm{s}=$ desvio padrão da média 
Tabela 12. Resíduos de deltametrina em grãos de pipoca, tratados com $0,35 \mathrm{mg} \cdot \mathrm{kg}^{-1}$ do inseticida, e em seu produto processado e concentração dos resíduos após o beneficiamento, 15 dias após aplicação.

\begin{tabular}{|c|c|c|c|c|c|c|}
\hline \multirow{2}{*}{ Tratamento } & \multirow{2}{*}{ Substrato } & \multicolumn{3}{|c|}{ Repetições } & \multirow{2}{*}{$\begin{array}{c}\text { Média } \\
\left(\mathrm{mg} \cdot \mathrm{kg}^{-1}\right) \\
\mathrm{m} \pm \mathrm{s}\end{array}$} & \multirow{2}{*}{$\begin{array}{c}\text { Indice de } \\
\text { concentração } \\
\text { dos resíduos }\end{array}$} \\
\hline & & a & b & c & & \\
\hline \multirow[t]{2}{*}{ grão tratado } & grão de pipoca & 0,23 & 0,22 & 0,25 & $0,23 \pm 0,02$ & 1 \\
\hline & pipoca & 0,35 & 0,35 & 0,42 & $0,37 \pm 0,04$ & 1,6 \\
\hline \multirow[t]{2}{*}{ testemunha } & grão de pipoca & $<0,02$ & $<0,02$ & $<0,02$ & $<0,02$ & - \\
\hline & pipoca & $<0,05$ & $<0,05$ & $<0,05$ & $<0,05$ & - \\
\hline
\end{tabular}

$\mathrm{m}=$ média

$\mathrm{s}=$ desvio padrão da média 
Tabela 13. Resíduos de deltametrina em grãos de pipoca, tratados com $0,35 \mathrm{mg} \cdot \mathrm{kg}^{-1}$ do inseticida, e em seu produto processado e concentração dos resíduos após o beneficiamento, 30 dias após aplicação.

\begin{tabular}{|c|c|c|c|c|c|c|}
\hline \multirow{2}{*}{ Tratamento } & \multirow{2}{*}{ Substrato } & \multicolumn{3}{|c|}{ Repetições } & \multirow{2}{*}{$\begin{array}{c}\text { Média } \\
\left(\mathrm{mg}^{\mathrm{kgg}}{ }^{-1}\right) \\
\mathrm{m} \pm \mathrm{s}\end{array}$} & \multirow{2}{*}{$\begin{array}{c}\text { Índice de } \\
\text { concentração } \\
\text { dos resíduos }\end{array}$} \\
\hline & & $\mathrm{a}$ & b & c & & \\
\hline \multirow[t]{2}{*}{ grão tratado } & grão de pipoca & 0,24 & 0,23 & 0,20 & $0,22 \pm 0,02$ & 1 \\
\hline & pipoca & 0,34 & 0,34 & 0,29 & $0,32 \pm 0,03$ & 1,5 \\
\hline \multirow[t]{2}{*}{ testemunha } & grão de pipoca & $<0,02$ & $<0,02$ & $<0,02$ & $<0,02$ & - \\
\hline & pipoca & $<0,05$ & $<0,05$ & $<0,05$ & $<0,05$ & - \\
\hline
\end{tabular}

$\mathrm{m}=$ média

$\mathrm{s}=$ desvio padrão da média 
Tabela 14. Resíduos de deltametrina em grãos de pipoca, tratados com $0,35 \mathrm{mg} \cdot \mathrm{kg}^{-1}$ do inseticida, e em seu produto processado e concentração dos resíduos após o beneficiamento, 60 dias após aplicação.

\begin{tabular}{llccccc}
\hline \hline Tratamento & Substrato & & Repetições & & $\begin{array}{c}\text { Média } \\
\left(\mathrm{mg} \cdot \mathrm{kg}^{-1}\right)\end{array}$ & $\begin{array}{c}\text { Índice de } \\
\text { concentração } \\
\text { dos resíduos }\end{array}$ \\
\hline \hline \multirow{2}{*}{ grão tratado } & $\mathrm{a}$ & $\mathrm{b}$ & $\mathrm{c}$ & $\mathrm{m} \pm \mathrm{s}$ & grão de pipoca \\
& & 0,26 & 0,22 & 0,21 & $0,23 \pm 0,02$ & 1 \\
& pipoca & 0,31 & 0,35 & 0,35 & $0,34 \pm 0,05$ & 1,5 \\
\hline \multirow{2}{*}{ testemunha } & grão de pipoca & $<0,02$ & $<0,02$ & $<0,02$ & $<0,02$ & - \\
& pipoca & $<0,05$ & $<0,05$ & $<0,05$ & $<0,05$ & - \\
\hline \hline
\end{tabular}

$\mathrm{m}=$ média

$\mathrm{s}=$ desvio padrão da média 
Tabela 15. Resíduos de deltametrina em grãos de pipoca, tratados com $0,35 \mathrm{mg} \cdot \mathrm{kg}^{-1}$ do inseticida, e em seu produto processado e concentração dos resíduos após o beneficiamento, 90 dias após aplicação.

\begin{tabular}{llccccc}
\hline \hline Tratamento & Substrato & & Repetições & & $\begin{array}{c}\text { Média } \\
\left(\mathrm{mg}^{-1} \mathrm{~kg}^{-1}\right) \\
\mathrm{m} \pm \mathrm{s}\end{array}$ & $\begin{array}{c}\text { Índice de } \\
\text { concentração } \\
\text { dos resíduos }\end{array}$ \\
\hline \hline \multirow{4}{*}{ grão tratado } & grão de pipoca & 0,24 & 0,24 & 0,23 & $0,24 \pm 0,006$ & 1 \\
& pipoca & 0,30 & 0,33 & 0,36 & $0,33 \pm 0,03$ & 1,4 \\
& & & & & & \\
testemunha & grão de pipoca & $<0,02$ & $<0,02$ & $<0,02$ & $<0,02$ & - \\
& pipoca & $<0,05$ & $<0,05$ & $<0,05$ & $<0,05$ & - \\
\hline \hline
\end{tabular}

$\mathrm{m}=$ média

$\mathrm{s}=$ desvio padrão da média 


\subsection{Análise de umidade de grãos e seus produtos processados}

Os resultados das análises de umidade dos grãos, pão e pipoca durante o período experimental encontram-se nas tabelas 16, 17, 18, 19 e 20.

De acordo com os resultados ocorreu perda de umidade durante o processamento do grão de milho pipoca em pipoca, sendo as umidades médias de 12,1 e 5\%, respectivamente. No caso do pão houve um aumento da umidade em relação as suas farinhas, que apresentavam em torno de $15 \%$ de umidade, enquanto o primeiro possuía em média 33,9\%, devido ao acréscimo de água para o preparo da massa do pão.

$\mathrm{O}$ aumento da umidade das farinhas em relação ao grão de trigo deve-se à necessidade do aumento da umidade dos grãos, em torno de 15,5\%, para que estes pudessem ser moídos.

Com relação a umidade dos grãos, os valores encontrados para o milho, mostraram uma tendência de estabilidade ao longo do período de armazenamento, em média $15,5 \%$, provavelmente devido a um equilibrio entre a umidade dos grãos e a umidade relativa do ambiente, que ficou em torno de $90 \%$. Já os grãos de trigo e milho pipoca apresentaram uma elevação contínua em suas umidades, supostamente ocasionada por absorção da umidade do ar, já que a umidade do ambiente onde as amostras foram acondicionadas era alta. 
Tabela 16. Resultados de análise de umidade em trigo.

\begin{tabular}{|c|c|c|c|}
\hline \multicolumn{4}{|c|}{ Umidade (\%) } \\
\hline \multirow[t]{2}{*}{ DAA } & & & Médias \\
\hline & $\mathbf{R}_{1}$ & $\mathbf{R}_{2}$ & \\
\hline 0 & 12,6 & 12,5 & 12,6 \\
\hline 30 & 12,8 & 12,8 & 12,8 \\
\hline 60 & 13,1 & 13,4 & 13,3 \\
\hline 90 & 13,6 & 13,5 & 13,6 \\
\hline
\end{tabular}

Tabela 17. Resultados de análise de umidade em milho.

\begin{tabular}{cccc}
\hline \hline DAA & Umidade (\%) & Médias \\
& $\mathbf{R}_{\mathbf{1}}$ & $\mathbf{R}_{\mathbf{2}}$ & \\
\hline & & & 15,8 \\
30 & 15,8 & 15,8 & 15,3 \\
60 & 15,3 & 15,3 & 15,1 \\
90 & 15,0 & 15,1 & 15,8 \\
\hline
\end{tabular}


Tabela 18. Resultados de análise de umidade em milho pipoca.

\begin{tabular}{cccc}
\hline \hline \multirow{2}{*}{ DAA } & $\mathbf{R}_{\mathbf{1}}$ & $\mathbf{R}_{\mathbf{2}}$ & Médias \\
\hline & 11,7 & 11,9 & \\
\hline 0 & 11,9 & 11,8 & 11,8 \\
60 & 12,4 & 12,3 & 11,9 \\
90 & 12,4 & 12,5 & 12,3 \\
\hline
\end{tabular}

Tabela 19. Resultados de análise de umidade de pão integral.

\section{Umidade (\%)}

DAA

\begin{tabular}{cccc}
\multicolumn{1}{c}{$\mathbf{R}_{\mathbf{1}}$} & $\mathbf{R}_{\mathbf{2}}$ \\
\hline 0 & 38,5 & 33,1 & 35,8 \\
15 & 30,9 & 30,8 & 30,9 \\
30 & 34,5 & 34,6 & 34,5 \\
60 & 34,4 & 34,5 & 34,5 \\
90 & 32,7 & 33,4 & 33,1 \\
\hline \hline
\end{tabular}


Tabela 20. Resultados de análise de umidade de pipoca.

\begin{tabular}{cccc}
\hline DAA & Umidade (\%) & Médias \\
& $\mathbf{R}_{\mathbf{1}}$ & $\mathbf{R}_{\mathbf{2}}$ & \\
\hline & & & 3,5 \\
15 & 3,3 & 3,6 & 6,4 \\
30 & 6,5 & 6,2 & 6,0 \\
60 & 5,8 & 6,1 & 4,2 \\
90 & 4,1 & 4,2 & 5,0 \\
\hline
\end{tabular}

Tabela 21. Dados de temperatura média (TM) e de umidade relativa média (URM) do local de armazenamento durante o período do experimento.

$\begin{array}{lll}06 \text { Jun. - 05 Jul. } & 21,6 & 86 \\ 06 \text { Jul. - 05 Ago. } & 22,5 & 90 \\ 06 \text { Ago. - 05 Set. } & 23,2 & 88\end{array}$




\subsection{Limite de quantificação e porcentagem de recuperação dos métodos}

Os resultados obtidos das porcentagens de recuperação de deltametrina em amostras de grãos de milho, trigo e pipoca e de seus respectivos produtos processados que foram fortificados como anteriormente descrito, são apresentados nas tabelas 22, 23 e 24.

Os cromatogramas típicos das fortificações de $0,01 \mathrm{mg} \cdot \mathrm{kg}^{-1}$ dos extratos de grão de trigo, farinha branca, farinha integral, pão, canjica, biju, farelinho; $0,02 \mathrm{mg} . \mathrm{kg}^{-1} \mathrm{de}$ grão de milho e milho pipoca e $0,05 \mathrm{mg} \cdot \mathrm{kg}^{-1}$ de farelo de trigo, farelo de milho e pipoca, bem como das testemunhas e dos padrões, são mostrados nas figuras de 2 a 16 .

Os valores acima citados são os limites de quantificação para cada substrato, os quais variam dependendo da quantidade de pigmentos e óleos contidos em cada material. Os substratos ricos em óleo e pigmentos, no caso farelos e pipoca, foram os que apresentaram o limite de quantificação mais alto, devido a interferência desses elementos nas análises, o que prejudica a resolução dos cromatogramas. 
Tabela 22. Porcentagem (\%) de recuperação de deltametrina, pelo método de análise de resíduos em amostras de grãos de trigo e seus produtos processados.

\begin{tabular}{|c|c|c|c|c|c|c|c|}
\hline \multirow{2}{*}{ Produto } & \multirow{2}{*}{ Repetições } & \multicolumn{6}{|c|}{ Níveis de fortificação (mg.kg ${ }^{-1}$ ) } \\
\hline & & 1,0 & 0,1 & 0,05 & 0,02 & 0,01 & 0,005 \\
\hline \multirow[t]{2}{*}{ grãos } & $\mathrm{A}$ & 112 & 78 & 79 & 100 & 94 & $\mathrm{LQ}^{*}$ \\
\hline & $\mathrm{B}$ & 84 & 90 & 82 & 94 & 89 & LQ \\
\hline \multirow[t]{2}{*}{ farinha branca } & $\mathrm{A}$ & 99 & 88 & 97 & 105 & 96 & LQ \\
\hline & $\mathrm{B}$ & 86 & 70 & 87 & 88 & 104 & LQ \\
\hline \multirow[t]{2}{*}{ farinha integral } & A & 75 & 84 & 102 & 101 & 87 & LQ \\
\hline & B & 94 & 89 & 112 & 110 & 136 & LQ \\
\hline \multirow[t]{2}{*}{ pão integral } & A & 106 & 95 & 100 & 125 & 118 & LQ \\
\hline & B & 85 & 72 & 96 & 128 & 104 & LQ \\
\hline \multirow[t]{2}{*}{ farelo } & A & 90 & 84 & 81 & LQ & LQ & LQ \\
\hline & B & 83 & 87 & 78 & LQ & LQ & LQ \\
\hline
\end{tabular}

* LQ = Limite de quantificação, quando o nível de fortificação apresenta recuperação fora do intervalo de 75 a $125 \%$. 
Tabela 23. Porcentagem (\%) de recuperação de deltametrina, pelo método de análise de resíduos em amostras de grãos de milho e seus produtos processados.

\begin{tabular}{|c|c|c|c|c|c|c|c|}
\hline \multirow{3}{*}{ Produto } & \multirow{3}{*}{ Repetições } & \multicolumn{6}{|c|}{ Niveis de fortificação (mg. $\left.\mathrm{kg}^{-1}\right)$} \\
\hline & & & & & & & \\
\hline & & 1,0 & 0,1 & 0,05 & 0,02 & 0,01 & 0,005 \\
\hline \multirow[t]{2}{*}{ grãos } & A & 101 & 95 & 87 & 109 & LQ* & LQ \\
\hline & B & 99 & 71 & 71 & 100 & LQ & LQ \\
\hline \multirow[t]{2}{*}{ canjica } & A & 85 & 70 & 83 & 97 & 104 & LQ \\
\hline & $\mathrm{B}$ & 79 & 83 & 84 & 92 & 108 & LQ \\
\hline \multirow[t]{2}{*}{ biju } & A & 112 & 104 & 97 & 93 & 130 & LQ \\
\hline & $\mathrm{B}$ & 108 & 100 & 78 & 107 & 119 & LQ \\
\hline \multirow[t]{2}{*}{ farelinho } & $\mathrm{A}$ & 87 & 90 & 99 & 100 & 132 & LQ \\
\hline & B & 94 & 103 & 93 & 100 & 104 & LQ \\
\hline \multirow[t]{2}{*}{ farelo } & A & 91 & 83 & 95 & LQ & LQ & LQ \\
\hline & B & 95 & 94 & 111 & LQ & LQ & LQ \\
\hline
\end{tabular}

* LQ = Limite de quantificação, quando o nível de fortificação apresenta recuperação fora do intervalo de 75 a $125 \%$. 
Tabela 24. Porcentagem (\%) de recuperação de deltametrina, pelo método de análise de resíduos em amostras de grãos de milho pipoca e em pipoca.

\begin{tabular}{|c|c|c|c|c|c|c|c|}
\hline \multirow{2}{*}{ Produto } & \multirow{2}{*}{ Repetições } & \multicolumn{6}{|c|}{ Níveis de fortificação $\left(\mathrm{mg} \cdot \mathrm{kg}^{-1}\right)$} \\
\hline & & 1,0 & 0,1 & 0,05 & 0,02 & 0,01 & 0,005 \\
\hline \multirow[t]{2}{*}{ grãos } & A & 91 & 83 & 74 & 118 & $\mathrm{LQ}^{*}$ & LQ \\
\hline & $\mathrm{B}$ & 91 & 85 & 94 & 117 & LQ & LQ \\
\hline \multirow[t]{2}{*}{ pipoca } & A & 82 & 85 & 77 & LQ & LQ & LQ \\
\hline & B & 93 & 83 & 84 & LQ & LQ & LQ \\
\hline
\end{tabular}

- $\mathrm{LQ}=$ Limite de quantificação, quando o nível de fortificação apresenta recuperação fora do intervalo de 75 a $125 \%$. 


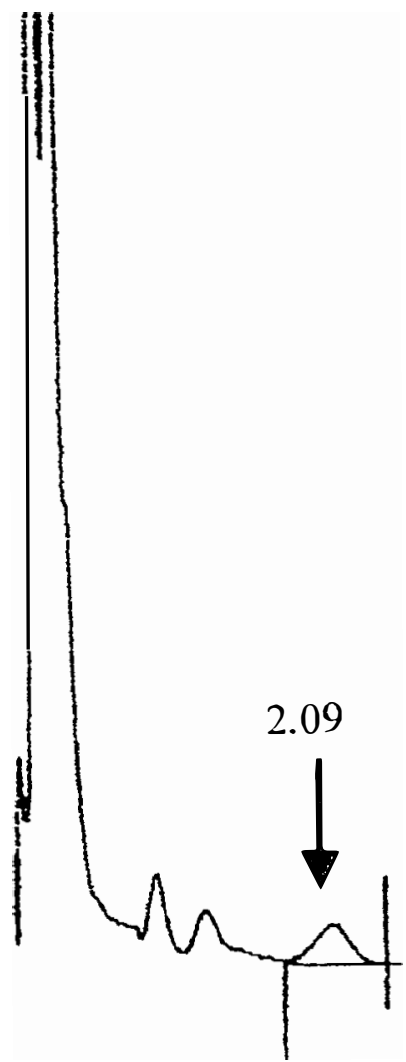

$\mathbf{a}$

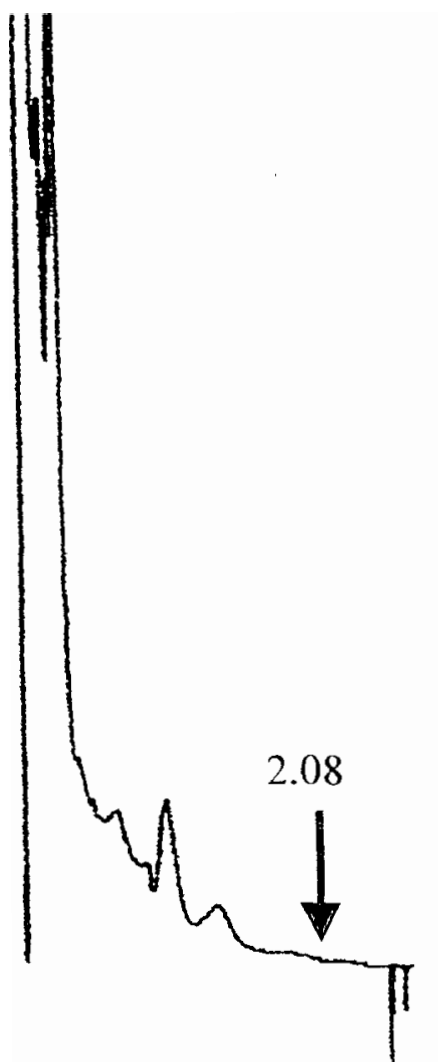

b

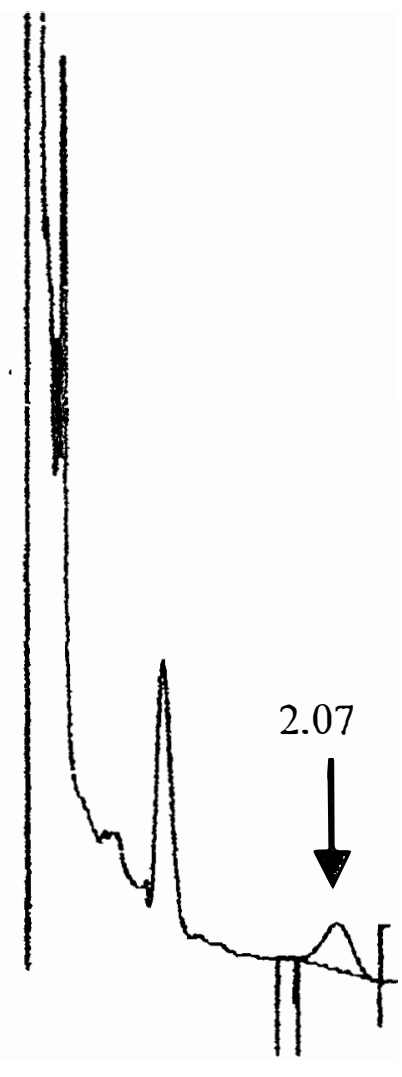

c

Figura 2. Cromatogramas de extratos de grão de trigo. a) padrão $2 \mu \mathrm{l}-20$ pg; b) testemunha $2 \mu \mathrm{l}-2 \mathrm{mg}$; c) fortificação $0,01 \mathrm{mg} \cdot \mathrm{kg}^{-1} / 2 \mu \mathrm{l}-2 \mathrm{mg}-20 \mathrm{pg}$ (mt). 


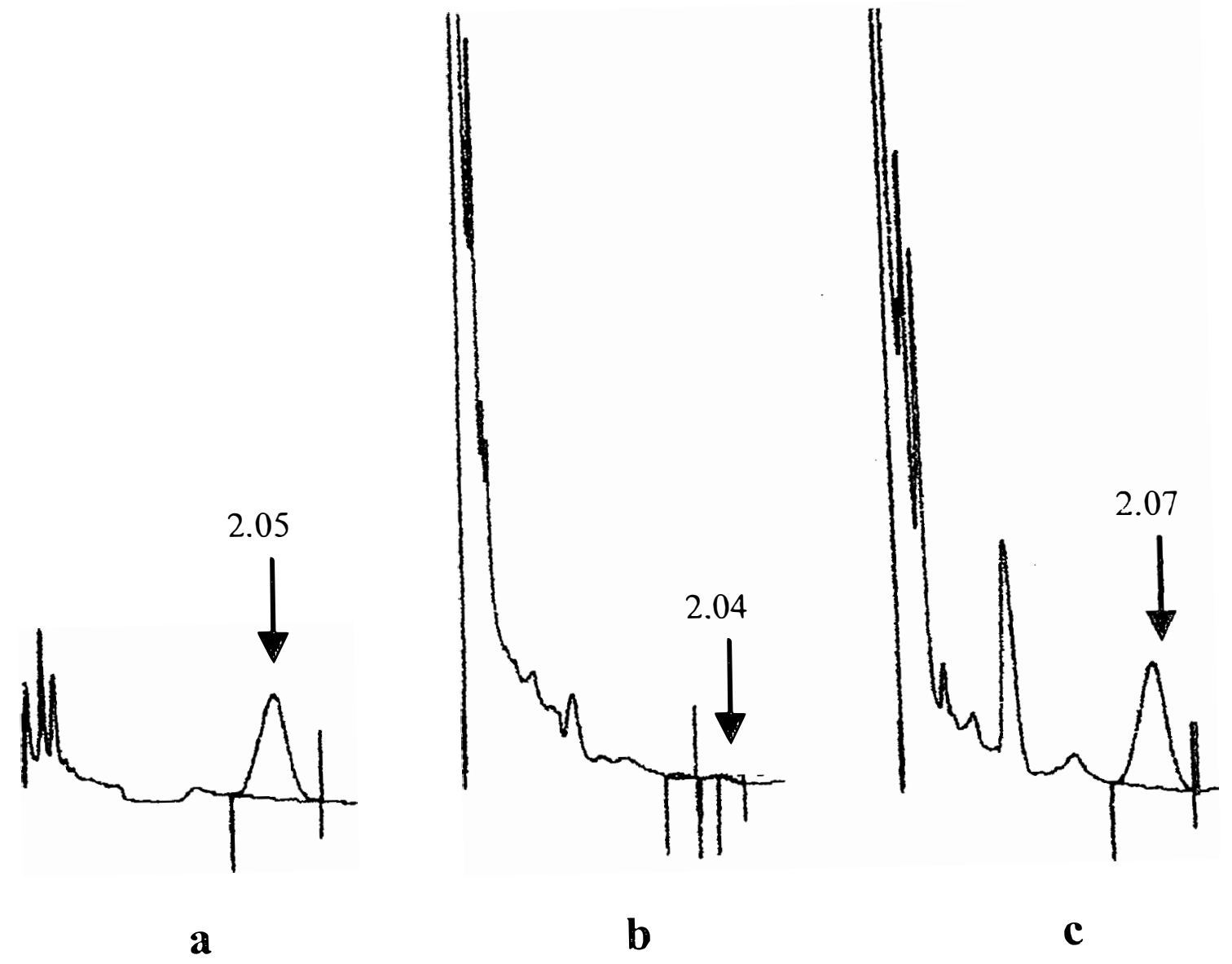

Figura 3. Cromatogramas de extratos de farelo de trigo. a) padrão $1 \mu \mathrm{l}-50 \mathrm{pg}$; b) testemunha $1 \mu \mathrm{l}-1 \mathrm{mg}$; c) fortificação de $0,05 \mathrm{mg} \cdot \mathrm{kg}^{-1} / 1 \mu \mathrm{l}-1 \mathrm{mg}-$ $50 \mathrm{pg}(\mathrm{mt})$. 


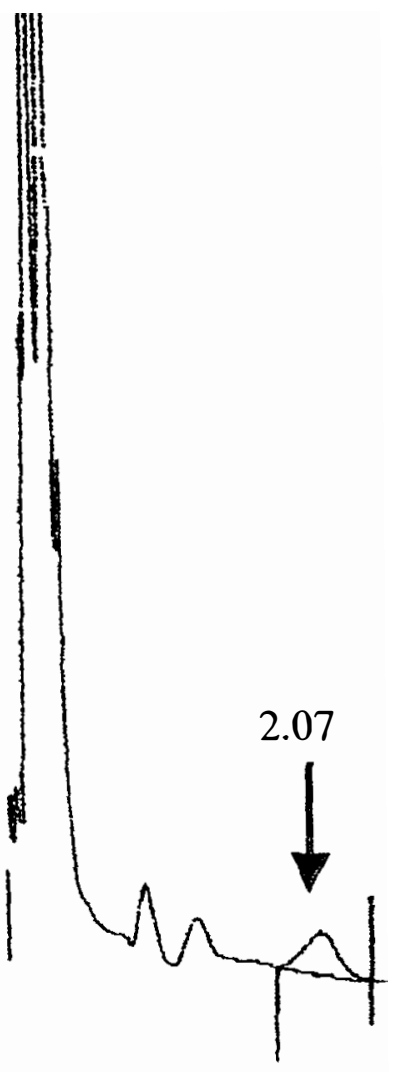

$\mathbf{a}$

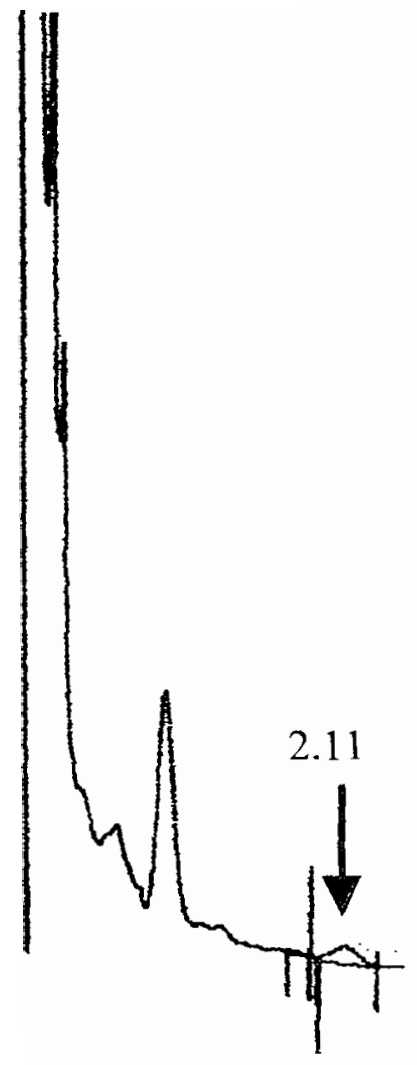

b

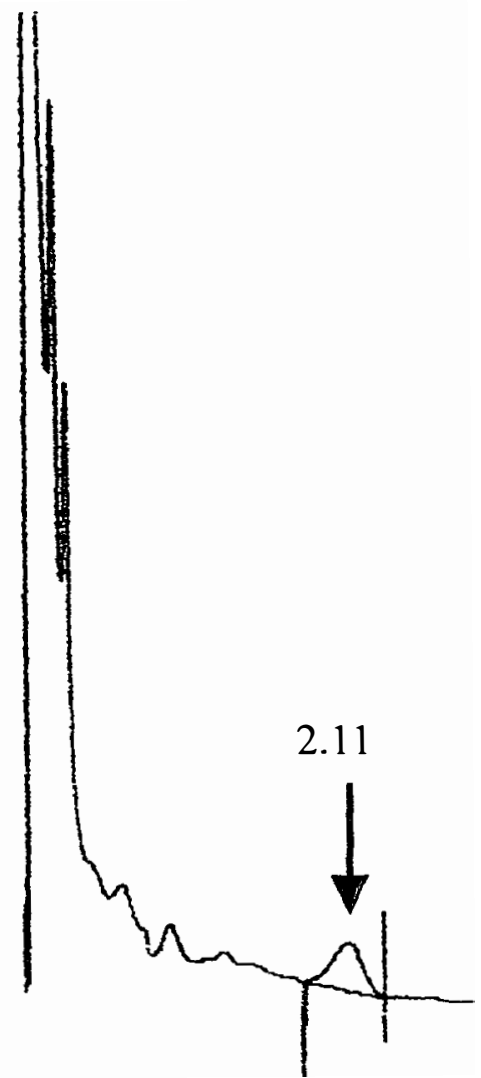

c

Figura 4. Cromatogramas de extratos de farinha branca. a) padrão $2 \mu \mathrm{l}-20 \mathrm{pg}$; b) testemunha $2 \mu \mathrm{l}-2 \mathrm{mg}$; c) fortificação de $0,01 \mathrm{mg} \cdot \mathrm{kg}^{-1} / 2 \mu \mathrm{l}-2 \mathrm{mg}-$ $20 \mathrm{pg}(\mathrm{mt})$. 


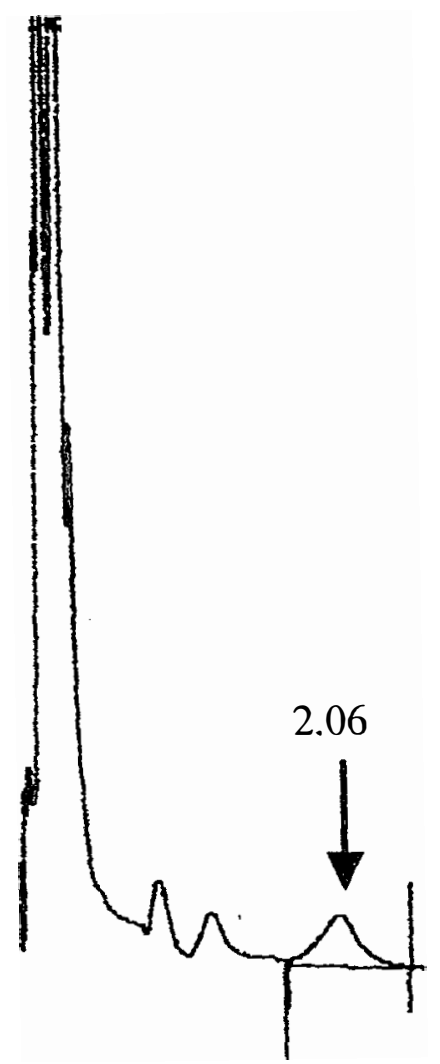

a

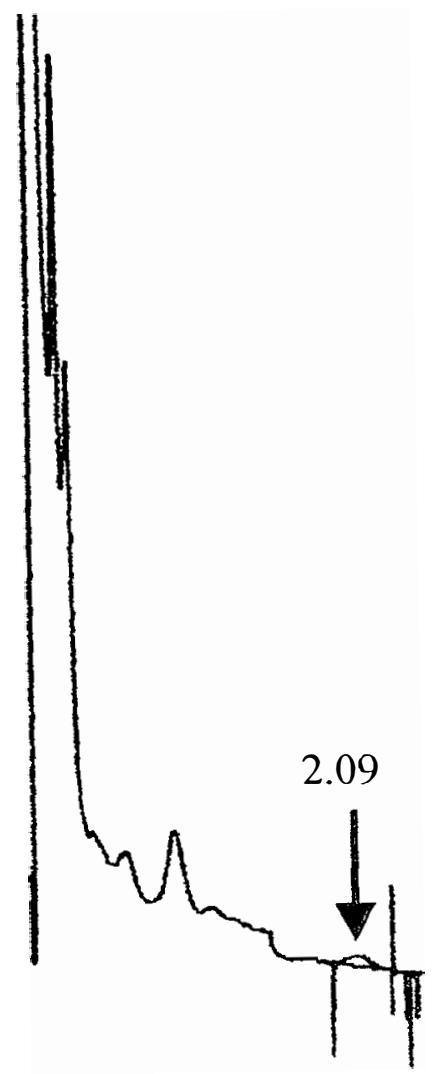

b

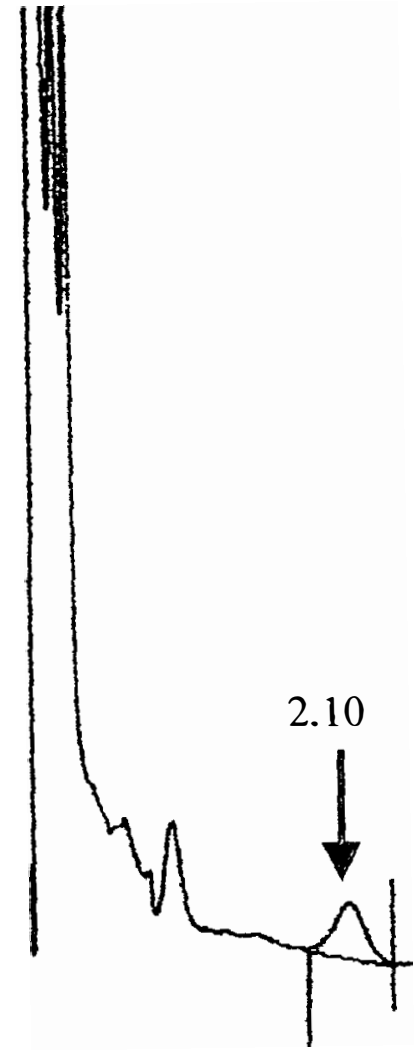

c

Figura 5. Cromatogramas de extratos de farinha integral. a) padrão $2 \mu \mathrm{l}-20 \mathrm{pg}$; b) testemunha $2 \mu \mathrm{l}-2 \mathrm{mg}$; c) fortificação de $0,01 \mathrm{mg} \cdot \mathrm{kg}^{-1} / 2 \mu \mathrm{l}-2 \mathrm{mg}-$ $20 \mathrm{pg}(\mathrm{mt})$. 


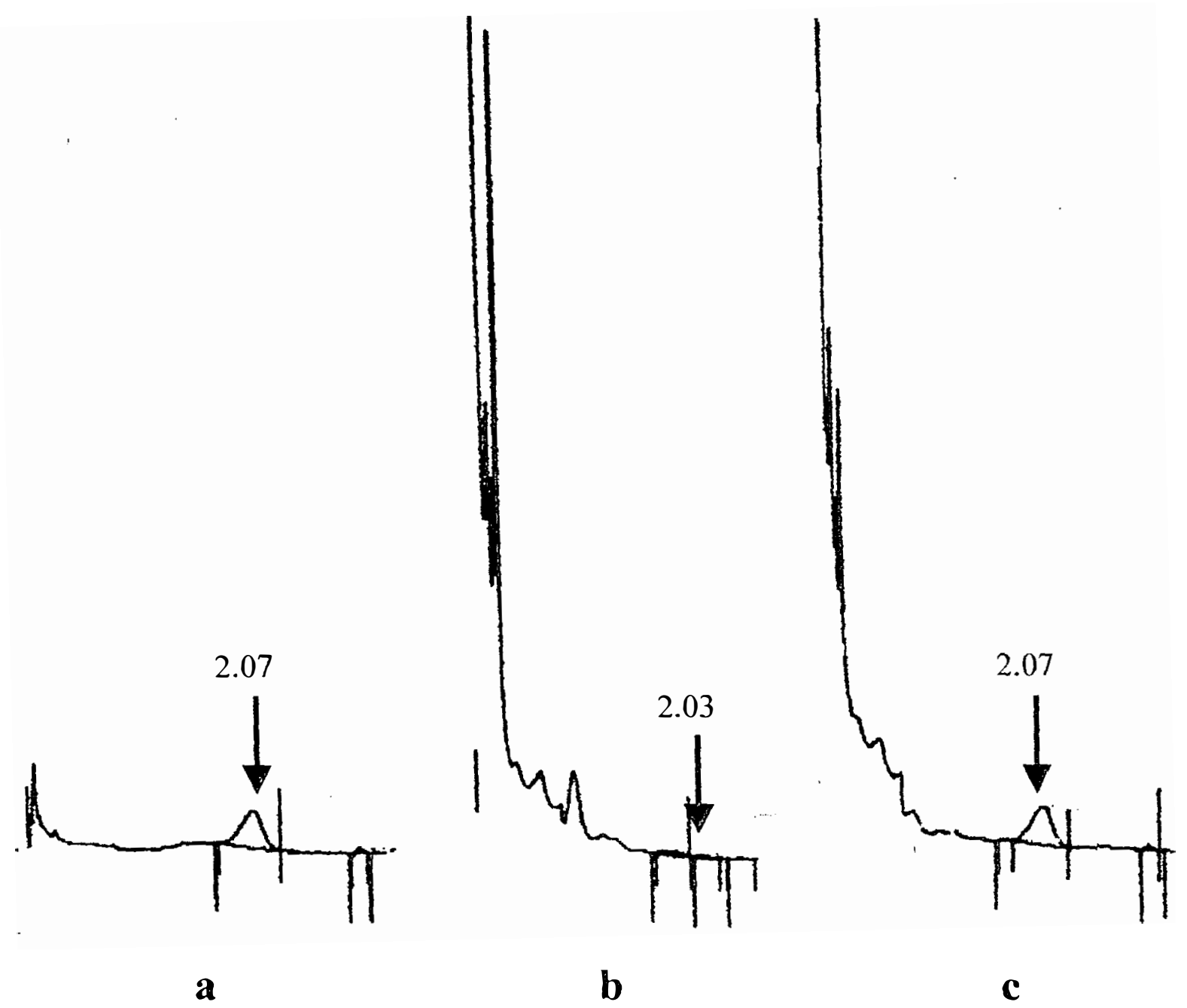

Figura 6. Cromatogramas de extratos de pão integral. a) padrão $2 \mu \mathrm{l}-20 \mathrm{pg}$; b) testemunha $2 \mu \mathrm{l}-2 \mathrm{mg}$; c) fortificação de $0,01 \mathrm{mg} \cdot \mathrm{kg}^{-1} / 2 \mu \mathrm{l}-2 \mathrm{mg}-50$ pg (mt). 


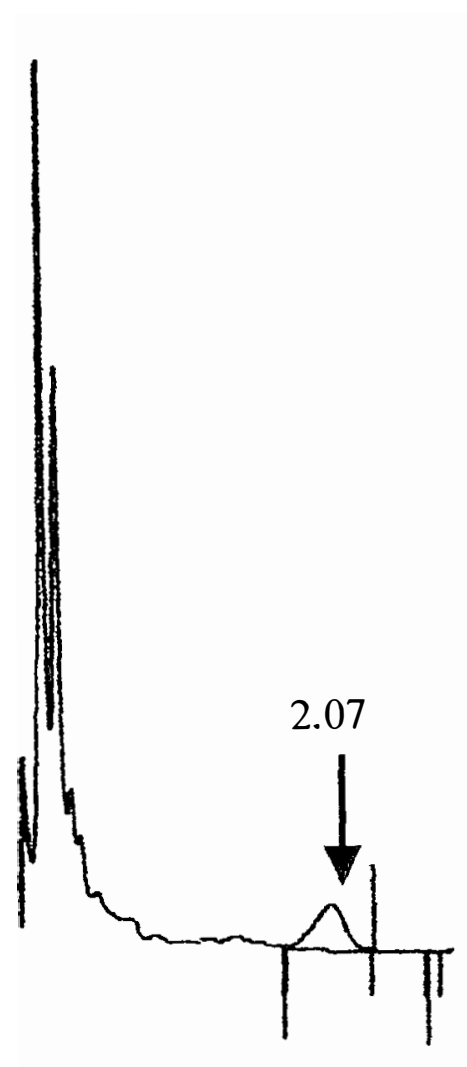

a

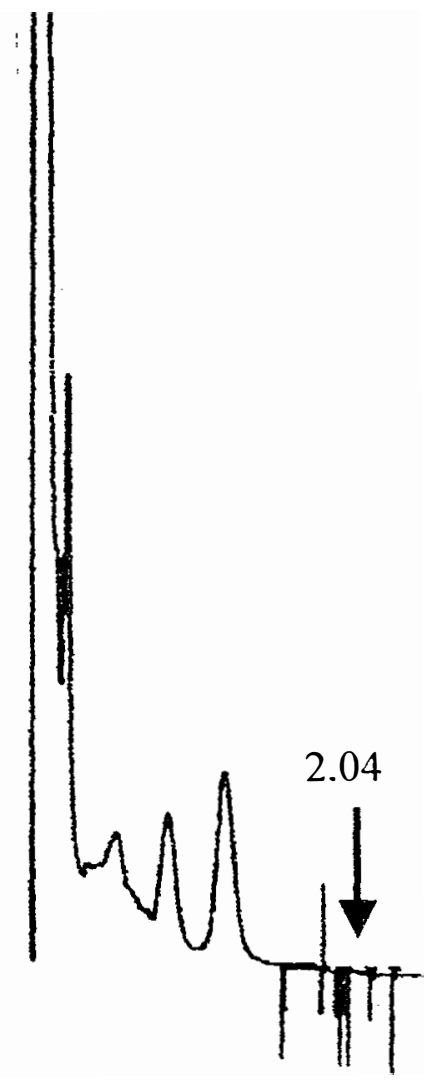

b

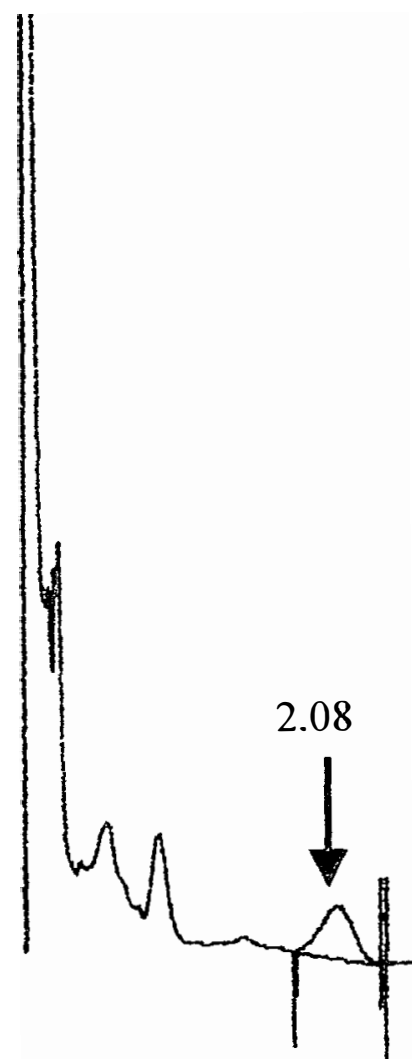

C

Figura 7. Cromatogramas de extratos de grão de milho. a) padrão $1 \mu \mathrm{l}-20$ pg; b) testemunha $1 \mu \mathrm{l}-1 \mathrm{mg}$; c) fortificação de $0,02 \mathrm{mg} \cdot \mathrm{kg}^{-1} / 1 \mu \mathrm{l}-1 \mathrm{mg}-20$ pg (mt). 


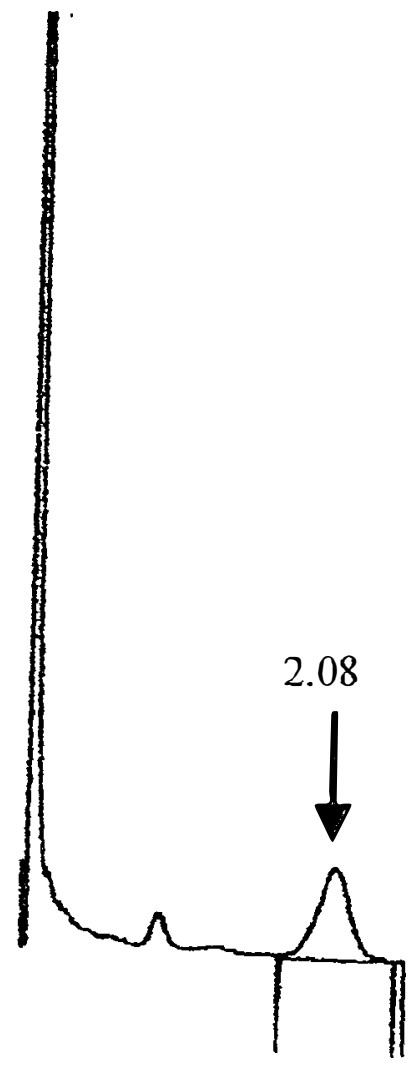

$\mathbf{a}$

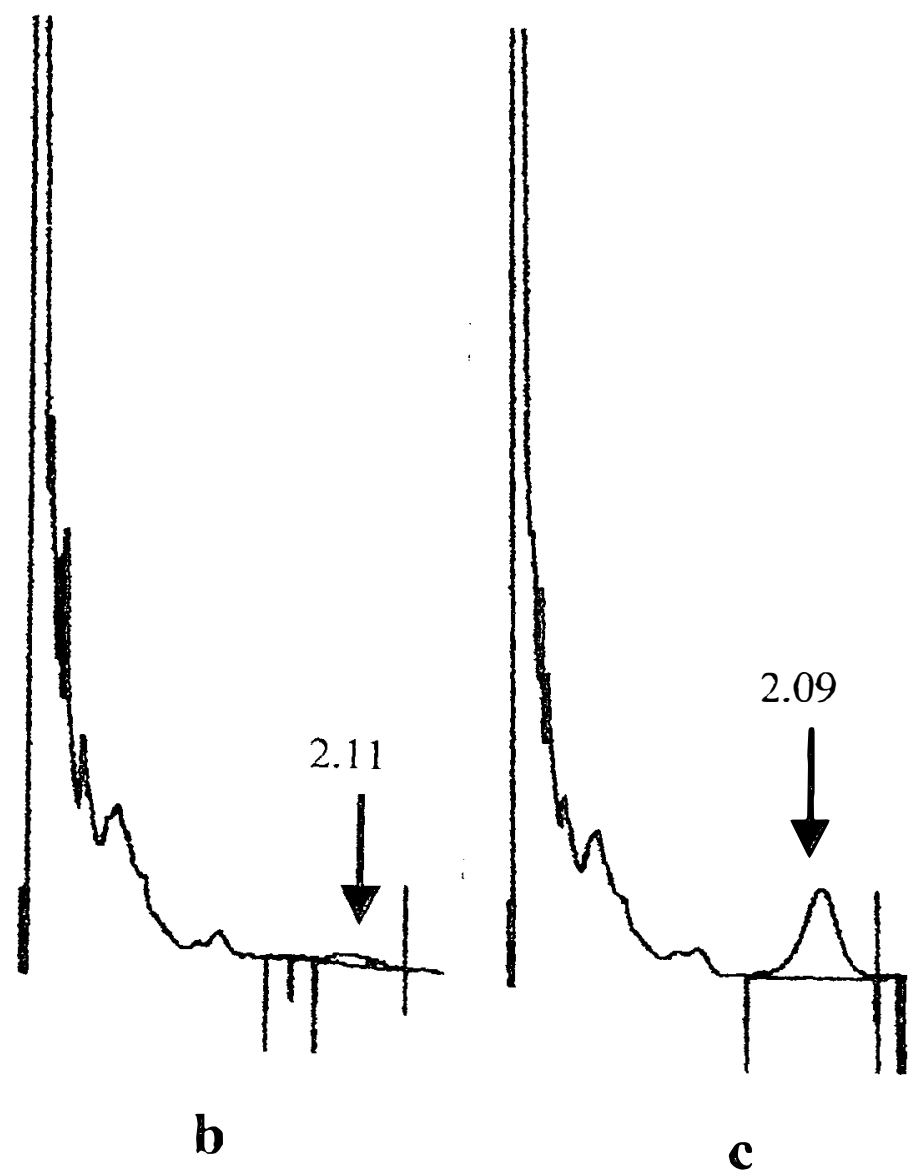

Figura 8. Cromatogramas de extratos de canjica. a) padrão $2 \mu l-40$ pg; b) testemunha $2 \mu \mathrm{l}-4 \mathrm{mg}$; c) fortificação $0,01 \mathrm{mg} \cdot \mathrm{kg}^{-1} / 2 \mu \mathrm{l}-4 \mathrm{mg}-40$ pg (mt). 


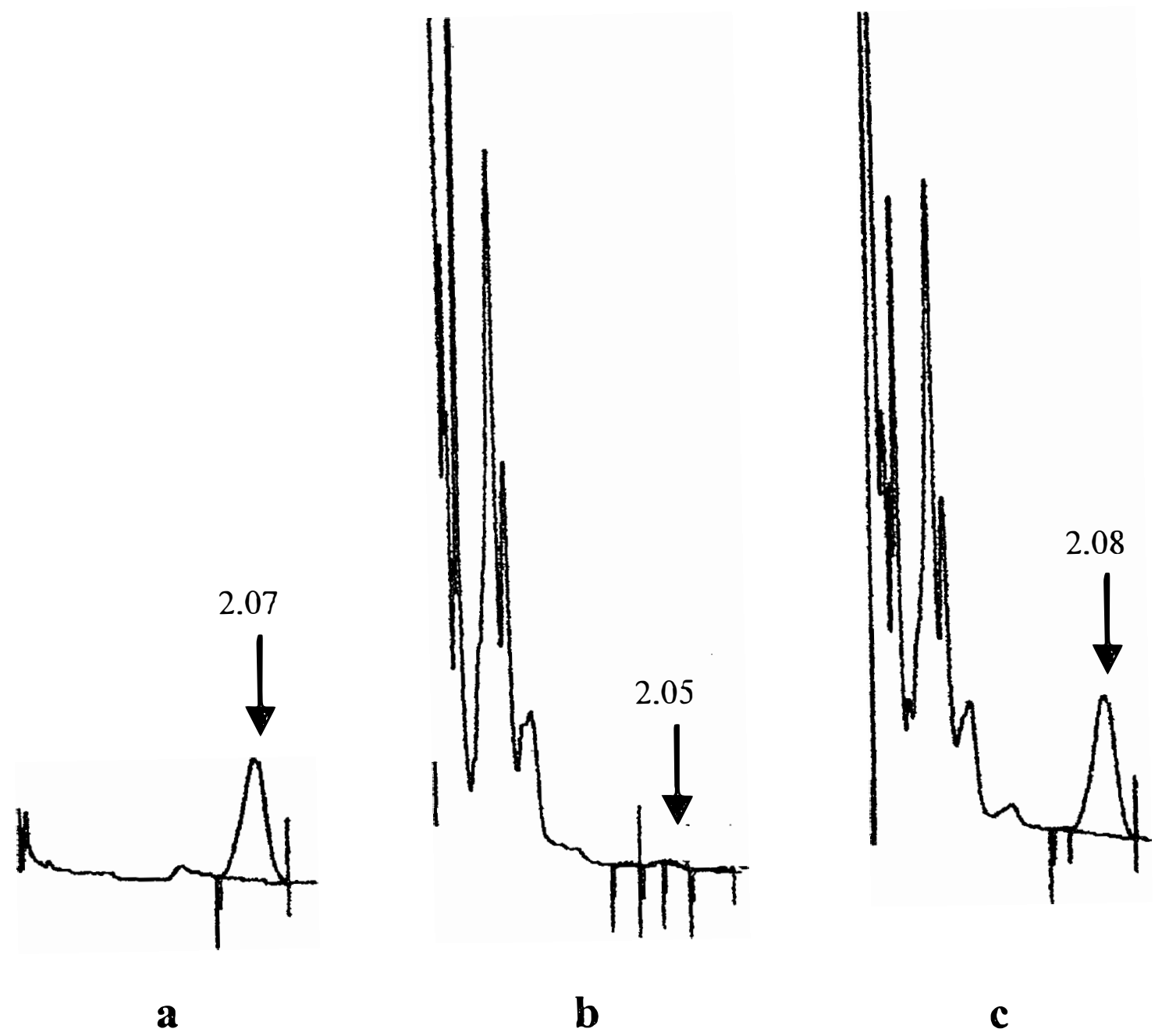

Figura 9. Cromatogramas de extratos de farelo de milho. a) padrão $1 \mu \mathrm{l}-50 \mathrm{pg}$; b) testemunha $1 \mu \mathrm{l}-1 \mathrm{mg}$; c) fortificação de $0,05 \mathrm{mg} \cdot \mathrm{kg}^{-1} / 1 \mu \mathrm{l}-1 \mathrm{mg}-50$ $\mathrm{pg}(\mathrm{mt})$. 


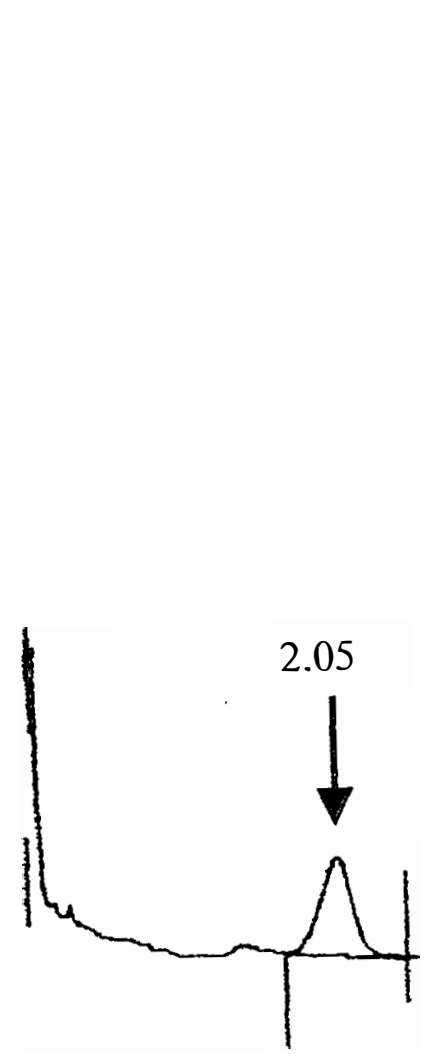

a

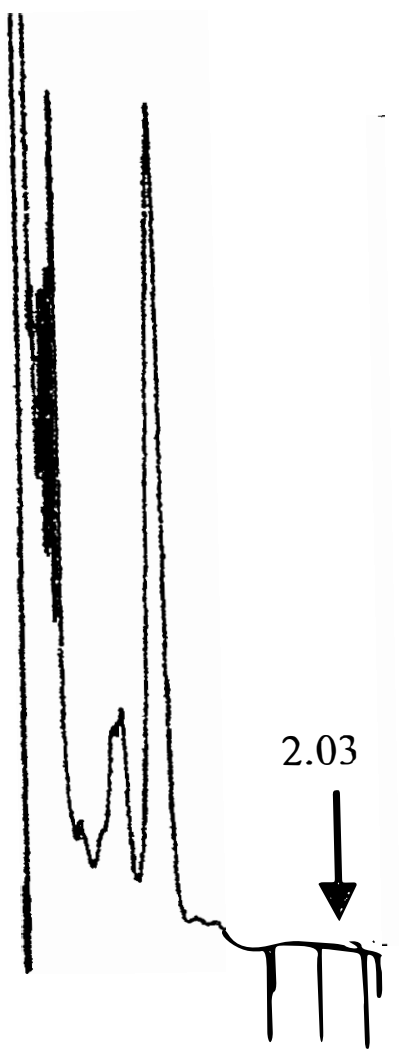

$\mathrm{b}$

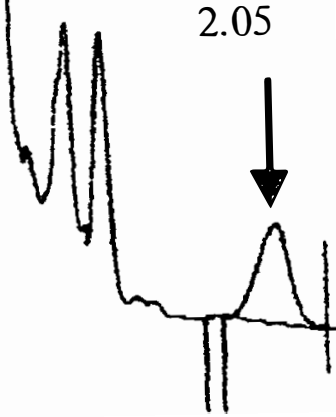

c

Figura 10. Cromatogramas de extratos de biju. a) padrão $2 \mu \mathrm{l}-40 \mathrm{pg}$; b) testemunha $2 \mu \mathrm{l}-4 \mathrm{mg} ; \mathrm{c})$ fortificação de $0,01 \mathrm{mg} \cdot \mathrm{kg}^{-1} / 2 \mu \mathrm{l}-4 \mathrm{mg}-40 \mathrm{pg}(\mathrm{mt})$. 


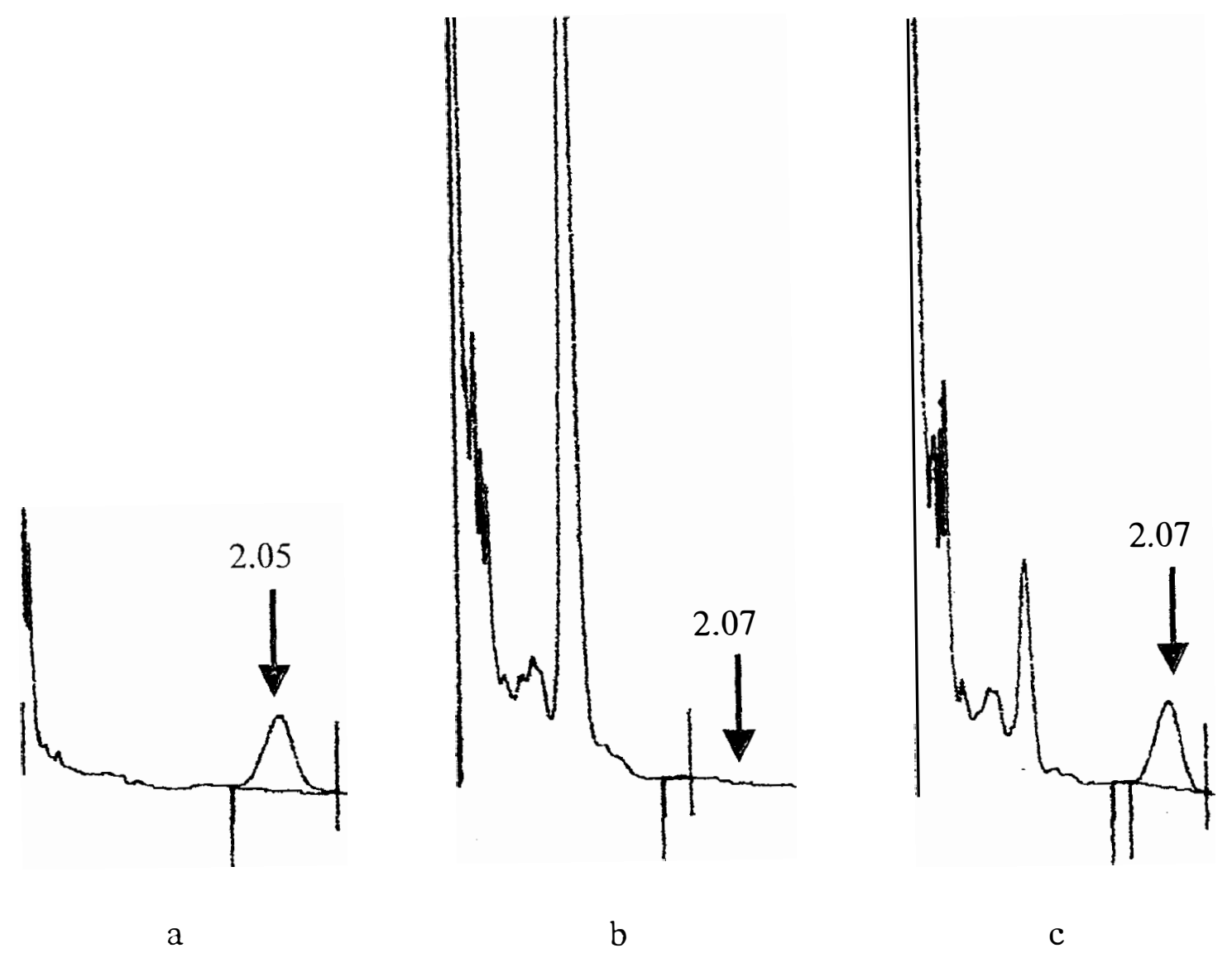

Figura 11. Cromatogramas de extratos de farelinho. a) padrão $2 \mu \mathrm{l}-40 \mathrm{pg}$; b) testemunha $2 \mu \mathrm{l}-4 \mathrm{mg}$; c) fortificação de $0,01 \mathrm{mg} \cdot \mathrm{kg}^{-1} / 2 \mu \mathrm{l}-4 \mathrm{mg}-$ $40 \mathrm{pg}$ (mt). 


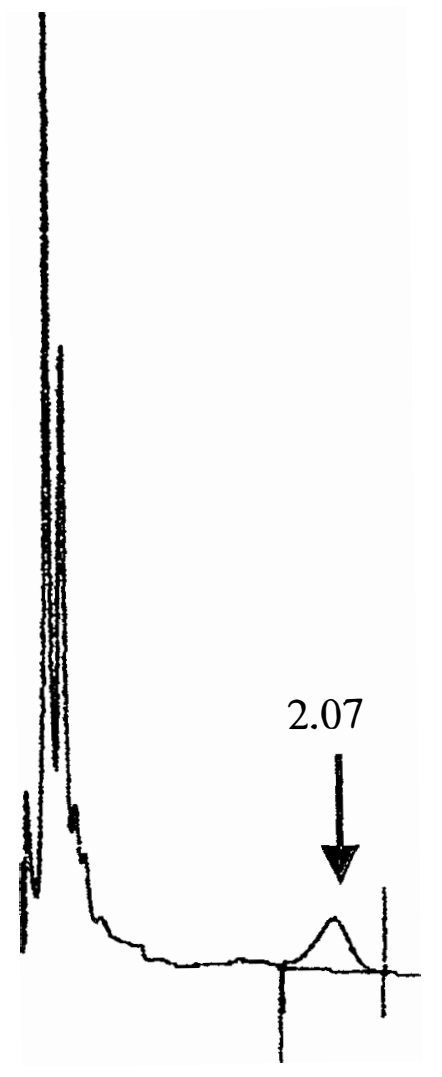

$\mathbf{a}$

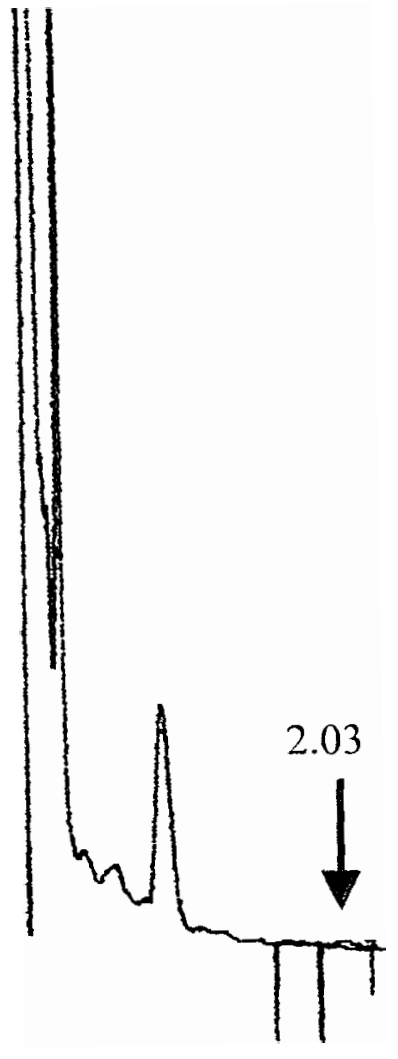

b

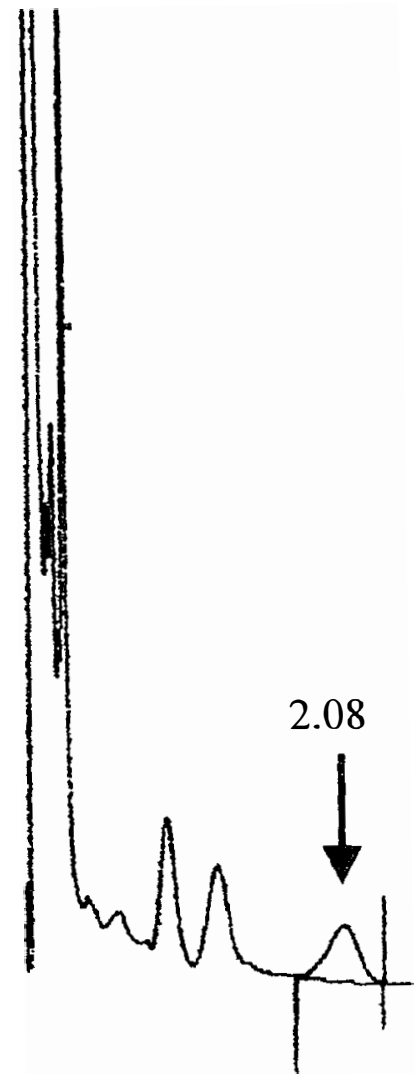

c

Figura 12. Cromatogramas de extratos de grão de milho pipoca. a) padrão $1 \mu \mathrm{l}-20 \mathrm{pg}$; b) testemunha $1 \mu \mathrm{l}-1 \mathrm{mg}$; c) fortificação de $0,02 \mathrm{mg} \cdot \mathrm{kg}^{-1} / 1 \mu \mathrm{l}-1 \mathrm{mg}-20$ pg (mt). 


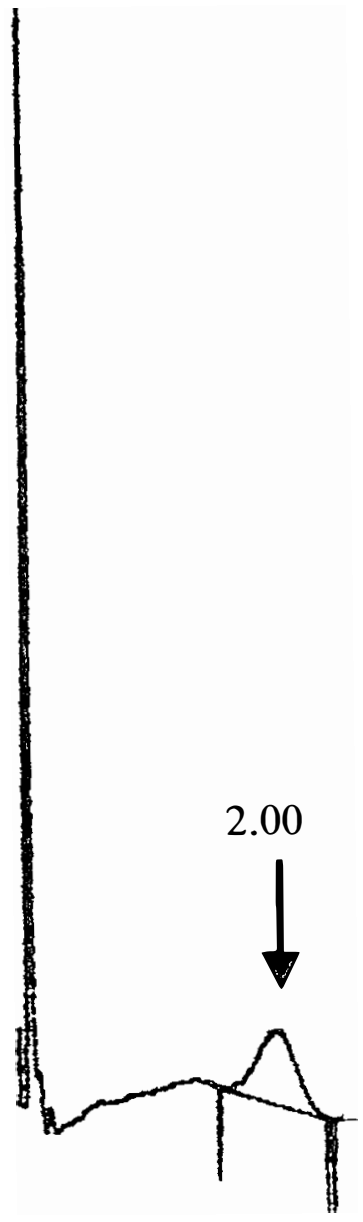

$\mathbf{a}$

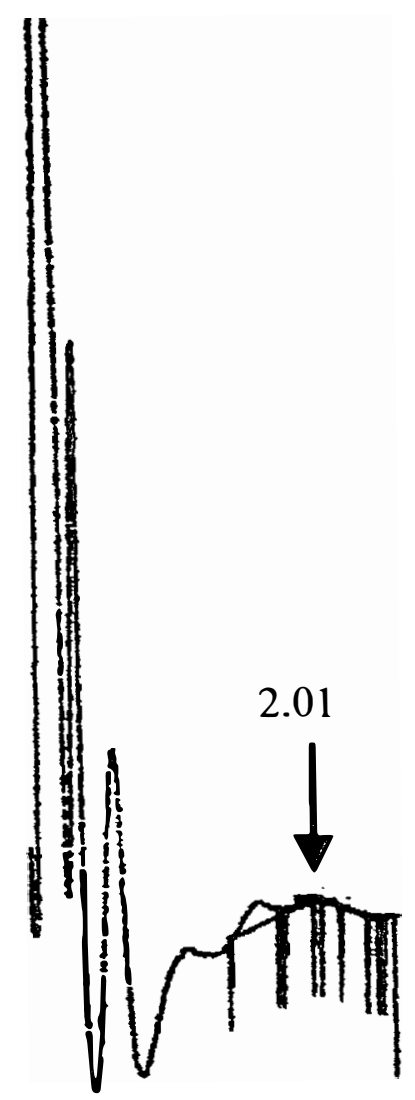

b

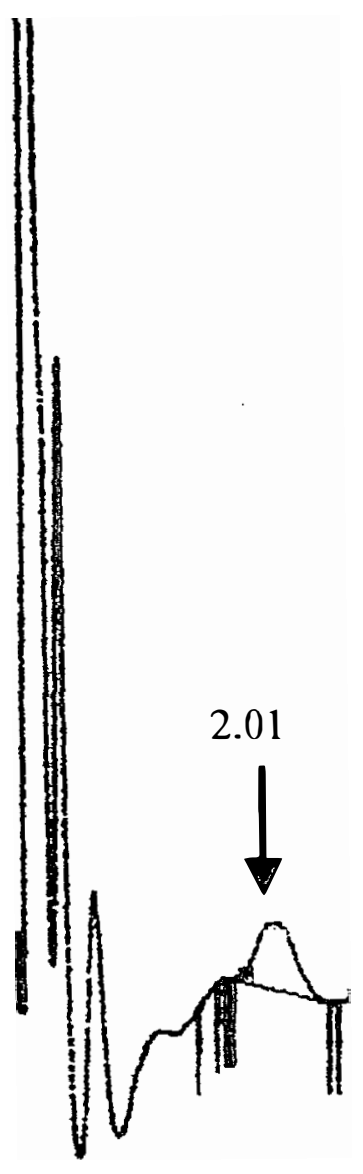

C

Figura 12. Cromatogramas de extratos de pipoca. a) padrão $1 \mu \mathrm{l}-50 \mathrm{pg}$; b) testemunha $1 \mu \mathrm{l}-1 \mathrm{mg}$; c) fortificação de $0,05 \mathrm{mg} \cdot \mathrm{kg}^{-1} / 1 \mu \mathrm{l}-1 \mathrm{mg}-50 \mathrm{pg}(\mathrm{mt})$. 


\section{CONCLUSÕES}

Nas condições em foi realizado o experimento, e de acordo com os resultados obtidos, pode-se concluir o seguinte:

a) O método analítico empregado para análise de resíduos de deltametrina em grãos de trigo, milho e milho pipoca e em seus produtos processados, mostra-se adequado, com limites de quantificação variáveis de 0,01 a $0,05 \mathrm{mg} \cdot \mathrm{kg}^{-1}$.

b) Resíduos de deltametrina são estáveis em grãos sob condições de armazenamento, por período de 90 dias ou mais.

c) Os resíduos de deltametrina em grãos de trigo concentram-se preferencialmente no farelo e em menores quantidades nas farinhas, sendo que o processo de cozimento do pão causa degradação desse inseticida.

d) Os resíduos de deltametrina em grãos de milho concentram-se em sua quase totalidade no farelo, não sendo detectados resíduos do piretróide na canjica, farelinho e biju.

e) No preparo da pipoca, pelo uso do forno de microondas, há concentração dos resíduos de deltametrina, em comparação ao grão. 


\section{REFERÊNCIAS BIBLIOGRÁFICAS}

ALLEONI, B. Resíduos de deltametrina, malation e pirimifós-metil em grãos de milho e suas ações sobre Rhyzopertha dominica (Fabr., 1972) (Coleoptera-Bostrichidae). Piracicaba, 1995. 80 p. Tese (Doutorado) - Escola Superior de Agricultura "Luiz de Queiroz”, Universidade de São Paulo.

ALNAJ, L.K.; KADOUM, A.M. Residues of methyl phoxim in wheat and milling fractions. Journal of Agricultural and Food Chemistry, v. 27, n. 3, p. 583-584, 1979.

ANDREI, E. Compêndio de defensivos agrícolas. 5. ed. São Paulo: Organização Andrei, 1996. 506p.

BAZZI, B.; SANTI, R.; CANALE, G.; RADICE, M. Applications of Cidial (phenthoate) in the control of insect pests of stored products. Metabolism, residues and technological/commercial and hygienic/sanitary implications. Instituto di Ricerche Agrarie, v. 11, p. 27-29, 1972. /Resumo em CAB Abstracts on CD-ROM, 72-75/.

BENGSTON. M.; CONNELL, M.; DAVIES, R.A.H.; DESMARCHELIER, J.M.; PHILLIPS, M.P.; SNELSON, J.T.; STICKA, R. Fenitrothion plus (1R) phenothrin, and pirimiphos-metyl plus carbaryl, as grain protectant combinations for wheat. Pesticide Science, v. 11, n. 5, p. 471-482, 1980. 
BENGSTON, M.; DAVIES, R.A.H.; DESMARCHELIER, J.M.; HENNING，R.; MURRAY, W.; SIMPSON, B.W.; SNELSON, J.T.; STICKA, R.; WALLBANK, B.E. Organophosphorothioates and synergised synthetic pyrethroids as grain protectants on bulk wheat. Pesticide Science, v. 14, n. 4, p. 373-384, 1983.

BRASIL. Ministério da Saúde. Relação de substâncias para uso fitossanitário e domissanitário: portarias do Ministério da Saúde. São Paulo: ILSI Brasil, 1995. $716 \mathrm{p}$.

BROWN, G.L.; PETAGINE, F.; OSBOURNE, B.G.; SEILER, D.A.L. The reduction of chemical and microbial contaminants in wheat. HGCA Project Report, v.35, p. 144, 1991. /Resumo em CAB Abstracts on CD-Rom, 1990-91/

COGBURN, R.R.; SIMONAITIS, R.A.; WEBB, B.D. Fate of malathion and chlorpirifos methyl in rough rice and milling fractions before and after parboiling and cooking. Journal of Economic Entomology, v. 83, n. 4, p. 1636-1639, Aug. 1990.

DESMARCHELIER, J.M. Grain protectants: trends and developments. In: INTERNATIONAL WORKING CONFERENCE ON STORED-PRODUCTS PROTECTION, 6., Camberra, 1994. Proceedings. Wallingford: CAB International. 1994. v. 2 , p. $722-728$.

FAO. Codex alimenta rius: pesticide residues in food; maximum residue limits. extraneous maximum residue limits. http:// apps.fao.org/cgi-bin/nph-db.pl (30 Set. 1998).

GALLO, D.; NAKANO, O.; SILVEIRA NETO, S.; CARVALHO, R.P.L.; BATISTA, G.C.; BERTI FILHO, E.; PARRA, J.R.P.; ZUCCHI, R.A.; ALVES, S.B.; VENDRAMIM, J.D. Manual de entomologia agrícola. 2. ed. São Paulo: Agronômica Ceres, 1988. cap. 8, p. 172-293: Métodos de controle das pragas. 
HALL, R.C.; BALLU, D.L.; BENNETT, G.W.; FAHEY, J.E. Persistence and distribution of Gardona and dichlorvos in grain and grain products. Journal of Economic Entomology, v. 66, n. 2, p. 315-318, Apr. 1973.

HOLLAND, P.T.; HAMLTON, D.; OHLIN, B.; SKIDMORE, M.W. Effects of storage and processing on pesticide residues in plant products. Pure and Applied Chemistry, v. 66, n. 2, p. 335-356, 1994.

JERMANNAUD, A.; POCHON, J.M. The fate of residues of deltamethrin in treated wheat during its transformation into food products. In: INTERNATIONAL WORKING CONFERENCE ON STORED-PRODUCTS PROTECTION, 6., Camberra, 1994. Proceedings. Walling ford: CAB International, 1994. v. 2, p. 798803.

JOIA, B.S.; WEBSTER, G.R.B.; LOSHIAVO, S.R. Cypermethrin and fenvalerate residues in stored wheat and milled fractions. Journal of Agricultural and Food Chemistry, v. 33, p. 618-622, 1985.

KADOUM, A.M.; LaHUE, D.W. Degradation of malathion in wheat and milling fractions. Journal of Economic Entomology, v. 70, n. 1, p. 109-1 10, 1977.

KADOUM, A.M.; LaHUE, D.W. Degradation of malathion on wheat and corn of various moisture contents. Journal of Economic Entomology, v. 72, p. 228-229, 1979.

KADOUM, A.M.; LaHUE, D.N.; ALNAJI, L. Efficacy and fate of pirimiphos-methyl residue applied at two dosage rates to wheat for milling. Journal of Economic Entomology, v. 71, n. 1, p. 50-52, Feb. 1978. 
L'HOTELLIER, M. Los residuos de deltametrín en los vegetales y otros productos alimenticios. In: RUSSEL UCLAF. Deltametrín: monografia. Saint-Pierre: Aubanel, 1983. cap. 8, p. 287-324.

LOCKWOOD, L. M. Organophosphate pesticides for use as grain protectants in India: Degradation of their residues during milling and cooking of cereal grains. 1973. 103 p. Thesis (Ph. D.) - Kansas State University. Dissertation Abstracts International B, v. 34, n. 1, p. 2-3, 1973.

MACIEL, E.; BAPTISTA, G.C.; TUKAMOTO, H.M. Resíduos de fenitrotion em farinha de trigo determinados por cromatografia em fase gasosa. In: CONGRESSO BRASILEIRO DE ENTOMOLOGIA, 14., Piracicaba, 1993. Resumos. Piracicaba: FEALQ, 1993. p.546.

McGAUGHEY, W.H. Malathion on milling fractions of three varieties of rough rice: Duration of protection and residues degradation. Journal of Economic Entomology, v. 64, n. 5, p. 1200-1205, Oct. 1971.

MENSAH, G.W.K.; WATTERS, F.L.; WEBSTER, G.R.B. Insecticide residues in milled fractions of dry or tough wheat treated with malathion, bromophos, iodofenphos and pirimiphos-methyl. Journal of Economic Entomology, v. 72, n. 5, p. 728-731, Oct. 1979.

NOBLE, R.M.; HAMILTON, J.; OSBORNE, W.J. Stability of pyrethroids on wheat in storage. Pesticide Science, v. 13, p. 246-252, 1982.

ONG, S.H.; RAHIM, M.; SULAIMAN, Z. Persistence of grain protectants in maize. In: INTERNATIONAL WORKING CONFERENCE ON STORED-PRODUCTS PROTECTION, 6., Camberra, 1994. Proceedings. Wallingford: CAB International, 1994. v. 2, p. 828-829. 
PAPADOPOULOU MOURKIDOU, E.; TOMAZOU, T. Persistence and activity of permethrin in stored wheat and its residues in wheat milling fractions. Journal of Stored Products Research, v. 27, n. 4, p. 249-254, 1991.

PEIXOTO, T.M.A.G.; FRANKLIN, H.M.O.H.; SANTOS, J.P.; NELSON, D.L. Influência do processamento e da temperatura sobre os resíduos de deltametrina em produtos preparados a partir de milho tratado. In: ENCONTRO NACIONAL DE ANALISTAS DE RESÍDUOS DE PESTICIDAS, 18., São Paulo, 1995. Relatório. São Paulo: Instituto Adolfo Lutz, 1995a. p. 122-120.

PEIXOTO, T.M.A.G.; FRANKLIN, H.M.O.Q.; SANTOS, J.P.; NELSON，D.L.; AZEVEDO, S.F. Persistência de deltametrina em espigas de milho armazenadas. In: ENCONTRO NACIONAL DE ANALISTAS DE RESÍDUOS DE PESTICIDAS, 18., São Paulo, 1995. Relatório. São Paulo: Instituto Adolfo Lutz, 1995b. p. 121129.

PUCCETI, G.; LUCA D', A.E. DE; COMI, R.; FORTINI, P.; MEATTA, M.; LEONI, V. Health aspects of using pirimiphos-methyl as a preservative for stored grain and presence of organophosphorus pesticide residues in cereal products. Igiene Moderna, v. 99, n. 2, p. 227-240, 1993.

SCHESSER, J.H.; PRIDDLE, W.E.; FARREL, E.P. Insecticidal residues in milling fractions from wheat treated with methoxychlor, malathion, and lindane. Journal of Economic Entomology, v. 51, n. 4, p. 516-518, Aug. 1958.

SINGH, S.; CHAWLA, R.P. Comparative persistence of residues of pirimiphos-methyl on stored wheat, maize and paddy. Bulletin of Grain Technology, v. 18, n. 3, p. 181-187, 1980. 
SKERRITT, J.H.; GRUIHOT, S.L.; HILL, A.S.; DESMARCHELIER, J.; GORE, P.J. Analysis of organophosphate, pyrethroid, and methoprene residues in wheat end products and milling fractions by immunoassay. Cereal Chemistry, v. 73 , n. 5, p. 605-612. 1996.

TEJADA, W.; CALUMPANG, S.M.F.; GAMBALAN, N.B. Effect of processing on residues of chlorpyrifos in stored corn and rice. The Philippine Agriculturist, v. 73 , n. 3, p. 375-385, July/Dec. 1990.

TESSIER, J. Estructura, sintesis y propriedades fisico-quimicas del deltametrín. In: RUSSEL UCLAF. Deltametrín: monografia. Saint-Pierre: Aubanel, 1983. cap. 2, p. 37-66.

TOMLIN, C. The pesticide manual. 10. ed. Bath: The Bath Press, 1995. p. 287-289: Deltamethrin.

VISWESWARAIAH， K.; ARCNIEGA， C.G.; SURYANARAYANA RAJU， G.; MAJUMDER, S.K. Fate of fenitrothion and methyl parathion residues during the process of wheat to various food products. Bulletin of Grain Technology, v. 21, n. 2, p. 134-140, 1983.

WEBLEY, D.J. Grain Protectants and Pesticides Residues. In: INTERNATIONAL WORKING CONFERENCE ON STORED-PRODUCTS PROTECTION, 6., Camberra, 1994. Proceedings. Walling ford: CAB International, 1994. v. 2, p. 857 862. 
APÊNDICES 
Apêndice 1. Relação de peso entre farinha branca, mistura e farelo de trigo obtidos de grãos de trigo tratados com $0,35 \mathrm{mg} / \mathrm{kg}$ de deltametrina.

\begin{tabular}{lccccc}
\hline \hline & & & DAA & \\
Produto & 0 & 15 & 30 & 60 & 90 \\
\hline \hline farinha branca & 46,3 & 48,0 & 50,6 & 48,2 & 56,4 \\
mistura & 30,2 & 31,1 & 27,3 & 25,5 & 18,8 \\
farelo de trigo & 23,5 & 20,9 & 22,1 & 26,3 & 24,8 \\
\hline \hline
\end{tabular}


Apêndice 2. Relação de peso entre canjica e farelo de milho obtidos de grãos de milho tratados com $0,35 \mathrm{mg} / \mathrm{kg}$ de deltametrina.

\begin{tabular}{lccccc}
\hline \hline & & \multicolumn{5}{c}{ DAA } \\
Produto & 0 & 15 & 30 & 60 & 90 \\
\hline \hline & & & & 71,6 & 72,4 \\
canjica & 74,2 & 75,3 & 73,7 & & \\
farelo de milho & 25,8 & 24,7 & 26,3 & 28,4 & 27,6 \\
\hline \hline
\end{tabular}

